\title{
Isotopic characteristics and paleoclimate implications of the extreme precipitation event of March 2015 in northern Chile
}

\author{
*Teresa E. Jordan ${ }^{1}$, Christian Herrera L. ${ }^{2}$, Linda V. Godfrey ${ }^{3}$, Stephen J. Colucci', \\ Carolina Gamboa P. ${ }^{2}$, Javier Urrutia M. ${ }^{2}$, Gabriel González L. ${ }^{2,4}$, Jacob F. Paul ${ }^{1}$
}

\author{
I Earth and Atmospheric Sciences, Cornell University, 112 Hollister Drive, Ithaca, New York, USA. \\ tej1@cornell.edu; sjc25@cornell.edu; jfp88@cornell.edu \\ 2 Departamento de Ciencias Geológicas, Universidad Católica del Norte, Av. Angamos 0610, Antofagasta, Chile. \\ cherrera@ucn.cl; gamboap.carolina@gmail.com;jum002@alumnos.ucn.cl;ggonzale@ucn.cl \\ 3 Earth and Planetary Sciences, Rutgers University, 610 Taylor Rd., Piscataway, New Jersey, USA. \\ lvgodfre@Eps.rutgers.edu \\ ${ }^{4}$ National Research Center for Integrated Natural Disaster Management, Av. Vicuña Mackenna 4860, Santiago, Chile.
}

* Corresponding author: tej1@cornell.edu

\begin{abstract}
Prior to the 24-26 March 2015 extreme precipitation event that impacted northern Chile, the scenarios for Pleistocene and Holocene wetter paleoclimate intervals in the hyperarid core of the Atacama Desert had been attributed to eastern or southwestern moisture sources. The March 2015 precipitation event offered the first modern opportunity to evaluate a major regional precipitation event relative to those hypothetical paleoclimate scenarios. It was the first opportunity to determine the ${ }^{18} \mathrm{O}$ and ${ }^{2} \mathrm{H}$ composition of a major precipitation event that might eventually be preserved in geological materials. The driver for the March 2015 event was a synoptic-scale weather system, a cutoff cold upperlevel low system that traversed the Pacific Ocean at a time of unusually warm temperatures of Pacific surface water. Ground-based precipitation data, stable isotopes in precipitation and river samples, NCEP/NCAR reanalysis atmospheric data and air mass tracking are utilized to connect the Earth surface processes to atmospheric conditions. The $\delta^{18} \mathrm{O}$ and $\delta^{2} \mathrm{H}$ of the precipitation and ephemeral rivers were significantly heavier than the rain, snow and ephemeral rivers fed by more frequent but less voluminous precipitation events registered prior to March 2015. Consistent with the atmospheric analyses, the rain isotopic compositions are typical of a water vapor whose source was at more equatorial latitudes of the Pacific and which moved southward. The late March 2015 system was an unforeseen scenario even for El Niño Pacific ocean conditions. Furthermore, the late summer season warmth led to greater potential for erosion and sediment transport than typical of more common moderate precipitation scenarios which usually include widely distributed snow. A comparison of the March 2015 scenario to the spatial distribution of wetter paleoclimate intervals leads to the hypothesis that the March 2015 scenario likely better fits some parts of the paleoclimate record of the continental interior hyperarid Atacama Desert than do the eastern or southwestern moisture source paleoclimate scenarios deduced previously.
\end{abstract}

Keywords: Extreme precipitation, Atacama Desert, $O$ and $H$ isotopes, Chile, Paleoclimate, Groundwater.

RESUMEN. Características isotópicas e implicaciones paleoclimáticas del evento de precipitación extrema de marzo de 2015 en el norte de Chile. Previo al evento de precipitación extrema que ocurrió entre el 24 y el 26 de marzo de 2015 y que impactó fuertemente en el norte de Chile, los escenarios de los intervalos paleoclimáticos más húmedos del Pleistoceno y Holoceno en el núcleo hiperárido del desierto de Atacama se habían atribuido sólo a fuentes de humedad provenientes del este o suroeste. El evento de precipitación de marzo de 2015 es la primera oportunidad de evaluar un hecho de precipitación regional importante en relación con los hipotéticos escenarios de paleoclima investigados previamente. Además, era la primera oportunidad de determinar la composición isotópica de ${ }^{18} \mathrm{O}$ y ${ }^{2} \mathrm{H}$ correspondiente a un evento mayor de precipitación que pudo, eventualmente, ser preservado en materiales geológicos. El evento de precitación de marzo de 2015 fue un sistema meteorológico de escala sinóptica, del tipo núcleo frío en 
altura que cruzó el oceáno Pacífico cuando las temperaturas superficiales del océano eran inusualmente elevadas debido al fenómeno de El Niño. Para comprender las relaciones entre los procesos desencadenados en la superficie de la Tierra y las condiciones atmosféricas prevalentes, se utilizaron datos de precipitación registrados en estaciones meteorológicas distribuidas regionalmente, isótopos estables de muestras de lluvia y ríos, el desarrollo de un reanálisis de datos atmosféricos NCEP/NCAR y un seguimiento de las masas de aire. Los valores isotópicos de $\delta^{18} \mathrm{O}$ y $\delta^{2} \mathrm{H}$ de la precipitación y los ríos efímeros fueron significativamente más pesados que la lluvia, la nieve y los ríos efímeros alimentados por precipitaciones más frecuentes, pero menos voluminosos que los registrados antes de marzo de 2015. Estas composiciones isotópicas coinciden con el análisis atmosférico en el sentido que son típicos de vapor de agua proveniente del oceáno Pacífico tropical. El evento extremo de marzo de 2015 no corresponde a los escenarios previstos para precipitaciones en el norte de Chile vinculadas a las condiciones El Niño. Además, su ocurrencia bajo temperaturas estivales provocó mayor capacidad de erosión y transporte de sedimentos, comparado con escenarios de precipitaciones más comunes y menos abundantes, que usualmente incluyen nieve ampliamente distribuida. De una comparación entre la distribución de precipitación en 2015 con mapas paleoclimáticos de intervalos más húmedos surge la hipótesis que el escenario de marzo de 2015 coincide mejor con ciertas partes del registro paleoclimático del desierto hiperárido de Atacama que los escenarios anteriormente propuestos.

Palabras clave: Precipitación extrema, Desierto de Atacama, Isótopos de O y H, Chile, Paleoclima, Agua subterránea.

\section{Introduction}

An uncommon precipitation event impacted northern Chile from 24-26 March 2015 (Fig. 1), at the end of the southern hemisphere summer season and at the onset of El Niño conditions in the Pacific Ocean. Because of the warm season, much of the precipitation fell as rain even in the high mountains where snowfall historically dominates. Whereas snow permits delayed and slowed surface run-off, the 2426 March 2015 region-wide run-off was rapid. The impacts included severe flooding of river valleys that drain the Andes to the Pacific coast with associated debris flows, tens of deaths, and widespread property damage (e.g., cities of Chañaral and Copiapó, Fig. 2) (Wilcox et al., 2016). Yet for regions of low relief or internal drainage there was little change of the land surface materials despite high rain totals (Jordan et al., 2015; Tapia et al., 2015; Wilcox et al., 2016; Scott et al., 2017). It is anticipated that groundwater was recharged, though spatial variations in recharge amount are not known.

Where precipitation is extremely infrequent and where historical documentation is incomplete, as in Chile's Atacama Desert, it is difficult to place an extreme precipitation event in a historical context. Viewed from the perspective of the last century, the March 2015 precipitation event was unprecedented, leading to questions such as: Was it representative of the normal weather fluctuations of late Holocene climate? Was it typical of past wetter conditions of the Late Pleistocene or Holocene? Does it herald the initiation of an unprecedented new climate state?
Details about paleoclimate, geomorphology or groundwater hydrology are valuable in answering these questions by providing a longer chronicle of precipitation and its spatial and temporal variability. However, published studies to date have not considered the March 2015 hydrometeorological scenario as a mechanism for late Pleistocene and Holocene wet paleoclimate periods (e.g., Gayó et al., 2012; Sáez et al., 2016). The objectives of this paper are to lay the foundation for reconsideration of existing paleoclimate and groundwater data sets and to show the need for the collection of new data from paleorecords that would enable comparison to the March 2015 precipitation event.

Climatologists underestimated the precipitation event: precipitation in the core of the hyperarid Atacama Desert had not previously been attributed to the set of atmospheric and oceanic circumstances which played out in March 2015. The event differed from all the previously documented precipitation scenarios expected in Chile during an El Niño event (Vargas et al., 2006). In mid March 2015 a southern hemisphere mid-latitude atmospheric wave disturbance evolved into a cold upper level cutoff low (Barrett et al., 2016) that traversed the Pacific Ocean (Fig. 1), reaching the South American coastline when subtropical and tropical eastern Pacific surface water was $1-3^{\circ} \mathrm{C}$ warmer than the mean for March (Barrett et al., 2016; Bozkurt et al., 2016). From 24-26 March rain and snow fell across approximately $400,000 \mathrm{~km}^{2}$ of subtropical Chile and western Argentina, 22-32 ${ }^{\circ} \mathrm{S}$ latitude (Fig. 2; Appendix Table A1), covering zones with hyperarid 


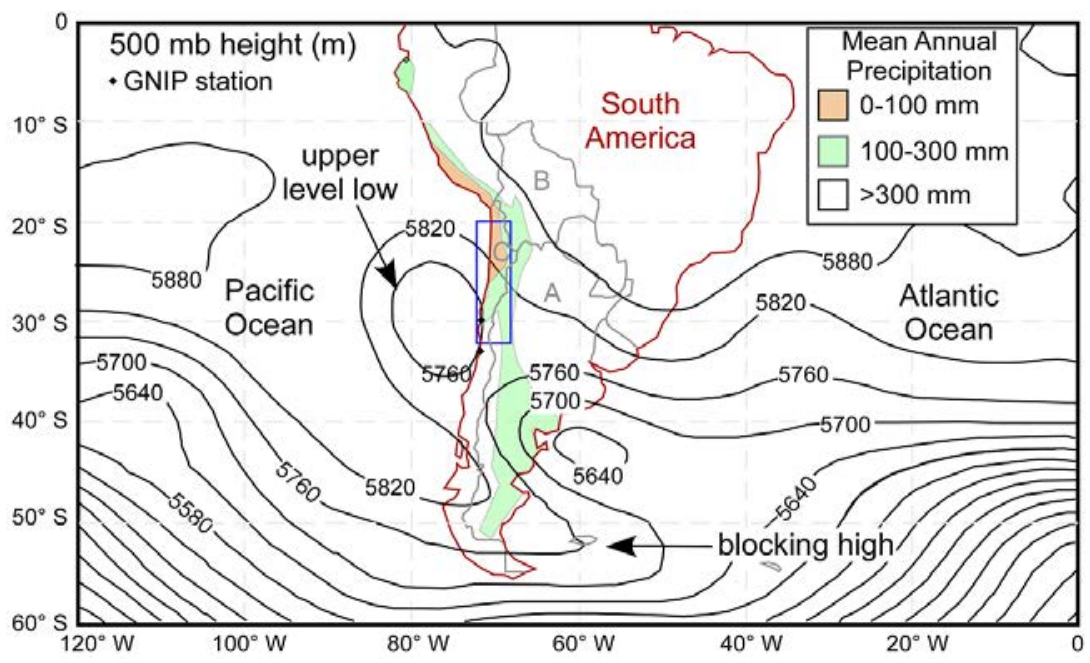

FIG. 1. Focus area for analysis of the consequences of the March 2015 rain (blue box) in context of the atmospheric conditions responsible for the precipitation. Height (meters above sea level) of $500 \mathrm{mb}$ atmospheric pressure on $24 \mathrm{March}$ 2015 at 9:00 PM Chile time (25 March 20150000 UTC). The closed contour of a low height zone defines the upper level cutoff low. National boundaries are gray lines, with labels for Chile (C), Bolivia (B) and Argentina (A). Colors indicate zones of semi-arid to hyperarid climate (zones of differing mean annual precipitation). Details for area within the blue rectangle are shown in figure 2B.

to semi-arid climates (Fig. 1). The boundary of transition from rain to snow near 3,600 $\mathrm{m}$ a.s.1. was uncommonly high.

In the hyperarid core of the Atacama Desert, the rain generated by this event exceeded decades of mean annual precipitation (Table 1). For example, historically (1988-2014) at the Aguas Verdes station $\left(25.4^{\circ} \mathrm{S}, 69.96^{\circ} \mathrm{W}\right)$ no March registered precipitation and, among December, January and February data, a single February (1998) registered $3.5 \mathrm{~mm}$. However, over the three days from 24-26 March 2015, this station received $85 \mathrm{~mm}$. In the hyperarid core of the desert, an event of this magnitude or greater likely dominates the modification of small scale landforms and the recharge of groundwater. Following this single event vegetation and flowering plants in particular covered wide areas in multiple locations, some of which had been barren for decades. An increase in vegetation on this scale becomes part of the paleoclimate record through storage of plant residue in rodent middens (e.g., Latorre et al., 2002; Latorre et al., 2006; Maldonado et al., 2005; Díaz et al., 2012; Gayó et al., 2012).

This paper documents the isotopic composition of precipitation from this rare event based on analyses of a unique set of rain and stream samples. The isotopic results are combined with analyses of atmospheric conditions to reveal the factors that produced the extreme precipitation and its isotopic fingerprint. The isotopic data for this event in combination with data from more commonplace events in northern Chile now offer diagnostic criteria for connecting past precipitation to atmospheric conditions.

\section{Hydroclimate zones and anticipated isotopic compositions}

The values of $\delta^{18} \mathrm{O}$ and $\delta^{2} \mathrm{H}$ in precipitation over the Andes Cordillera and intermediate elevation terrain between the Andes and the Pacific coast reflect multiple atmospheric water vapor transport paths and the orographic effects of the Andes (Fig. 2A). The dominant water vapor transport paths to the northern and southern ends of the region impacted by the March 2015 event are different, tied to latitudinal gradients in hemispheric-scale atmospheric circulation, sea surface temperature gradients, and topography.

Atmospheric water vapor that leads to precipitation comes from at least three spatially separated sources (Aceituno, 1988; Rutllant and Fuenzalida, 1991; Houston and Hartley, 2003; Garreaud et al., 2009) (Fig. 2A) which define three separated climate zones (Zone I, Zone II and Zone III, Fig. 2B). The area between climate zones I, II, and III constitutes the hyperarid core of the Atacama Desert, zone IV. South of $22^{\circ} \mathrm{S}$ (northern part of the political division "II Region 


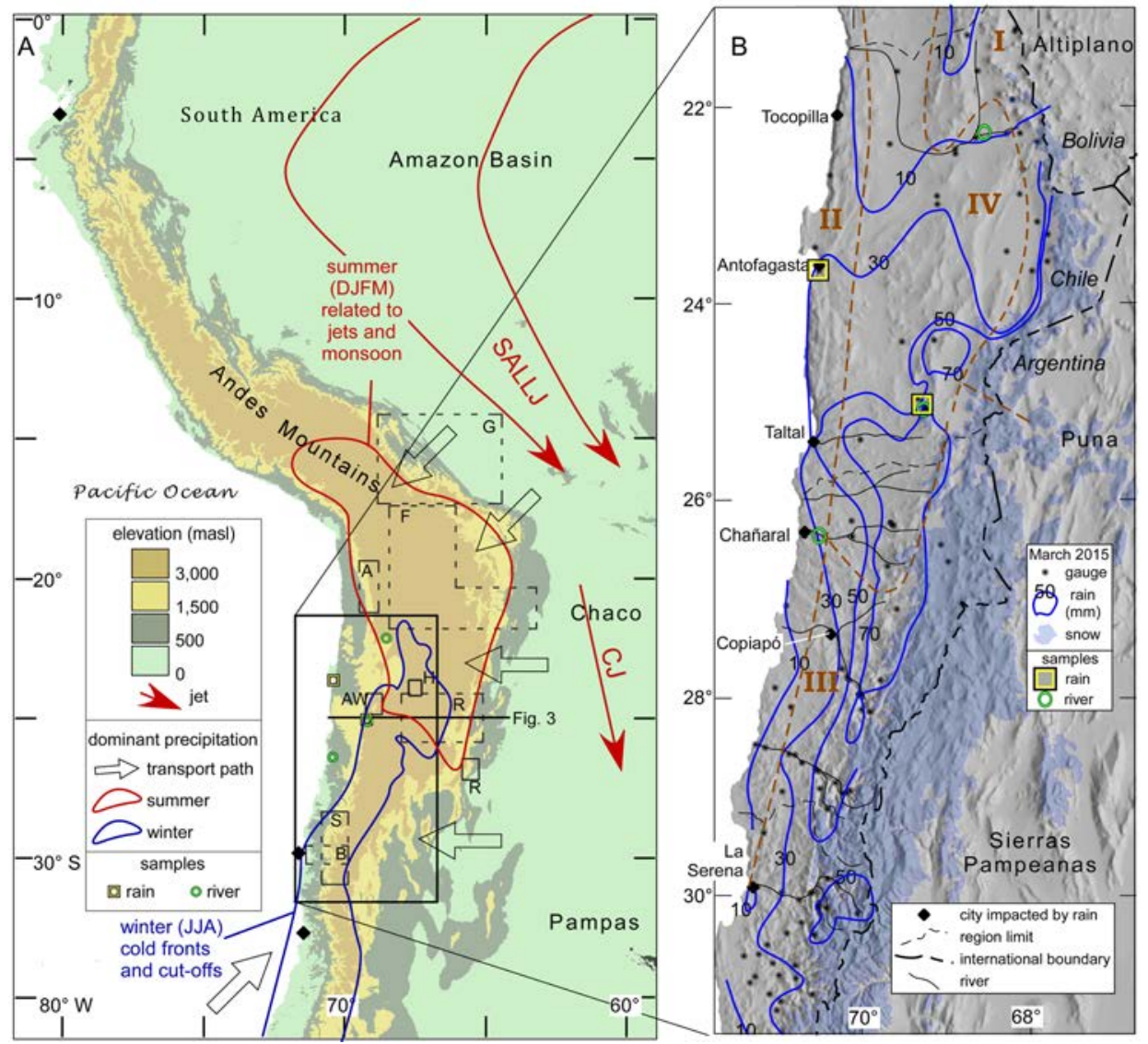

FIG. 2. Regional precipitation climate system of western South America, the precipitation distribution for the March 2015 event, and water sample locations. A. Topography of west central South America (colors) is dominated by the Andes Mountains which are a barrier to air masses. Regions in the Andes Mountains that are outlined in blue receives winter precipitation from the south and southwest. The Andean region outlined in red receives most precipitation during summer months, derived from Atlantic Ocean sources via the Amazon Basin. Low level atmospheric jets (red streamlines and arrows) are a principal control on water vapor pathways: the summer season South American Low-Level Jet (SALLJ) and Chaco Jet (CJ). Gray-outline arrows schematically show water vapor delivery paths. Gray dashed-line boxes show regions with published water isotope data from samples of precipitation and/or surface streams in regions whose precipitation climatology is linked to that of northern Chile (Fig. 4). A: studies of Fritz et al. (1981); Aravena et al. (1999), and Uribe et al. (2015); S: studies of Strauch et al. (2009); B: work by Burgener et al. (2016); AW: studies by Alpers and Whittemore (1990); H: studies by Herrera et al. (2016); R: studies by Rohrmann et al. (2014); G: studies by Gonfiantini et al. (2001); F: studies by Fiorella et al. (2015). B. Rainfall for 23-27 March 2015 (contours in millimeters based on the station data given in Appendix Table A1) and snowfall distribution for March 2015 event (from satellite data). Dashed brown lines and Roman numerals demarcate major hydroclimate zones: IV is the hyperarid core of the Atacama Desert.

of Antofagasta"), Pacific-sourced water vapor leads to precipitation in the Andes Mountains dominantly in winter (June-July-August) (zone III) (Houston and Hartley, 2003; Burgener et al., 2016). Through cutoffs and fronts from the mid-latitude westerlies (Vuille and Ammann, 1997) a decreasing amount of precipitation reaches progressively northward. North of $25^{\circ} \mathrm{S}$ (southern part of the political division
"II Region of Antofagasta"), the persistent southeast Pacific subtropical high pressure system so effectively blocks the entry of fronts in the westerlies onto the continent (Rutllant and Fuenzalida, 1991) that this winter Pacific-sourced precipitation beyond $25^{\circ} \mathrm{S}$ is of very small amount, and we designate that to be the northern boundary of zone III. Along a coastal strip (zone II), low level stratocumulus clouds beneath a 
TABLE 1. MEAN ANNUAL PRECIPITATION AT SELECTED LOCATIONS IMPACTED BY MARCH 2015 EVENT, AND PRECIPITATION DURING MARCH 2015 EVENT.

\begin{tabular}{|c|c|c|c|c|c|}
\hline Location name & Latitude & Longitude & $\begin{array}{l}\text { March 23-27, } 2015 \\
\text { event }(\mathrm{mm})\end{array}$ & $\begin{array}{l}\text { Annual mean } \\
(\mathbf{m m})\end{array}$ & $\begin{array}{c}\text { Source of } \\
\text { Mean Annual } \\
\text { Precipitation }\end{array}$ \\
\hline Calama & 22.47 & 68.92 & 11.8 & 3.2 & 1 \\
\hline Antofagasta airport & 23.45 & 70.45 & 12.4 & 4.1 & 1 \\
\hline Peine & 23.68 & 68.07 & 26.5 & 23.1 & 1 \\
\hline Yungay & 24.10 & 70.02 & $\sim 35$ & 2.4 & 2 \\
\hline Aguas Calientes & 25.30 & 69.83 & $\sim 85$ & 4.7 & 2 \\
\hline Taltal & 25.40 & 70.48 & 30 & 11 & 3 \\
\hline El Salvador & 26.25 & 69.63 & 77.4 & 22.6 & 4 \\
\hline Caldera & 27.07 & 70.82 & 10.5 & 20 & 3 \\
\hline Pastos Grandes & 27.11 & 69.56 & 86.1 & 31 & 3 \\
\hline Copiapó city & 27.38 & 70.33 & 23.4 & 18 & 3 \\
\hline $\begin{array}{l}\text { Jorquera en la } \\
\text { Guardia }\end{array}$ & 27.84 & 69.76 & 83 & 47 & 3 \\
\hline Lautaro & 27.98 & 70.00 & 70 & 36 & 3 \\
\hline Manflas & 28.13 & 69.98 & 87 & 46 & 3 \\
\hline
\end{tabular}

1. Houston and Hartley, 2003.

2. Warren-Rhodes et al., 2006.

3. Dirección General de Aguas, $2009^{1}$.

4. Luchinger Moyano, 2013.

persistent temperature inversion produce Pacificsourced fog, especially during the winter (Houston and Hartley, 2003). The third typical moisture source, of Atlantic origin via the Amazon basin, is responsible for providing precipitation to zone I during summer months. During summer the change in the strength of the South American Low Level Jet (SALLJ, Fig. 2A) and southward shift of the intertropical convergence zone lead to an enhanced supply of moisture to the high altitude plateau (Altiplano) within the southern tropics (Garreaud et al., 2009). Under conditions of diminished westerly flow over northernmost Chile, that Atlantic-sourced tropical air mass spreads westward, providing summer precipitation to the western Andean cordillera (Garreaud et al., 2009). Although another path of summer season water vapor delivery from the South American lowlands southeast of the Atacama Desert was established by Vuille and Keimig (2004) which would contribute to zones I and III, a lack of documentation of specific cases in which this mode caused rain in the Atacama Desert suggests that it may contribute less to total rainfall than the other sources.

For the west coast of South America, the $\delta^{18} \mathrm{O}$ and $\delta^{2} \mathrm{H}$ of precipitation derived from Pacific-sourced water vapor (Fig. 3A) vary from tropical sites that are only slightly lower than SMOW (Standard Mean Ocean Water) (Esmeraldas and La Cuca, Ecuador) to sub-tropical and mid-latitude sites (La Serena and Valparaíso, Chile), whose monthly isotopic values are much more variable and generally more negative. Data for the stable isotope compositions of precipitation in the hyperarid part of the Atacama Desert are sparse (Fritz et al., 1981; Alpers and Whittemore, 1990; Aravena et al., 1999). Summer rain that falls on the western slope of the Andes tends to be less depleted in heavy isotopes than rains east of the topographic divide in the Altiplano (Fig. 3B) (Fritz et al., 1981;

${ }^{1}$ Dirección General de Aguas, 2009. Evaluación de los recursos hídricos subterráneos en cuencas de la región de atacama ubicadas entre el Río Copiapó y la región de Antofagasta. Informe Técnico de Administración de Recursos Hídricos. Ministerio de Obras Públicas: 45 p. Santiago. 


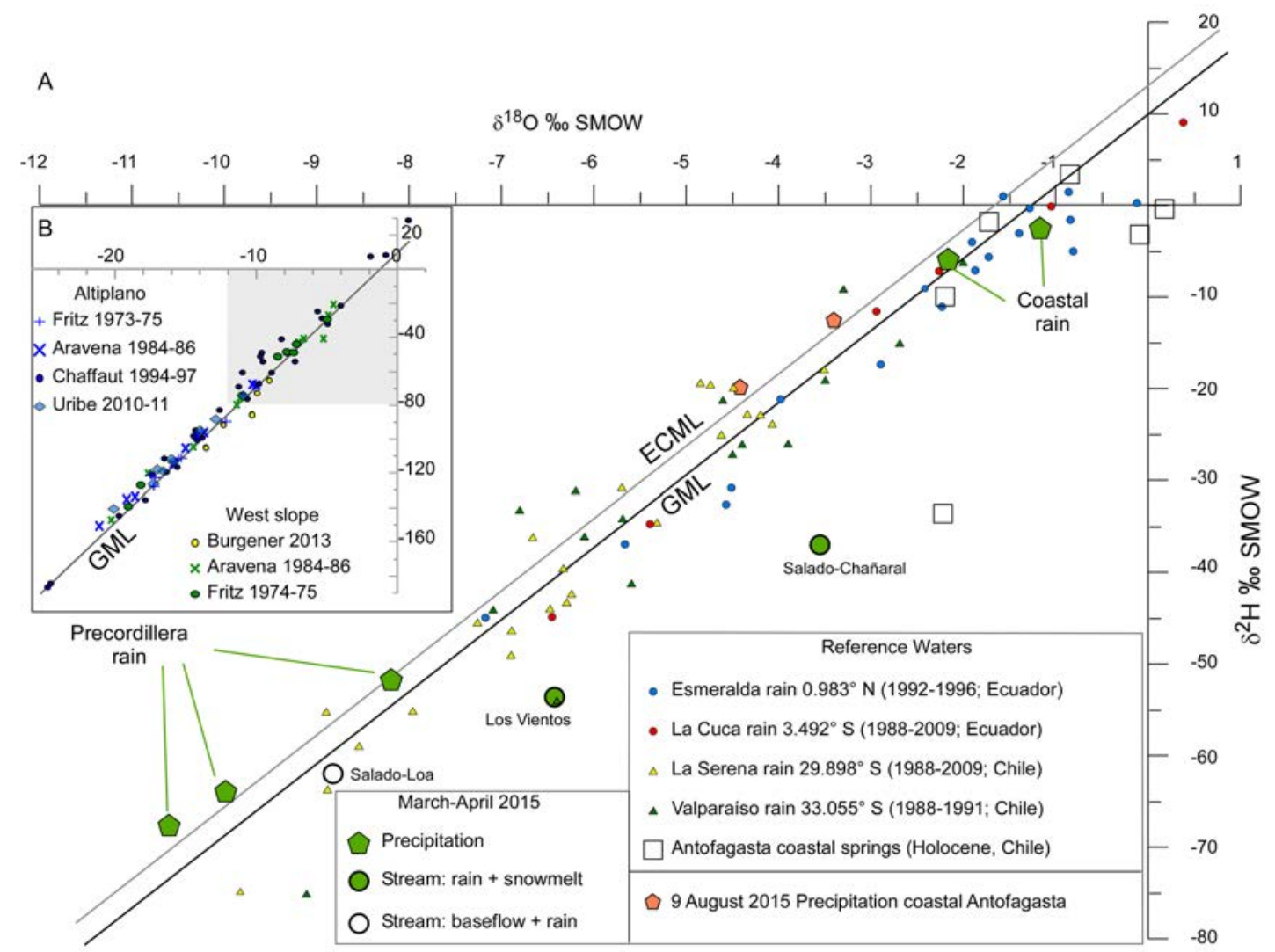

FIG. 3. Published data for $\delta^{18} \mathrm{O}$ and $\delta^{2} \mathrm{H}$ composition of precipitation along the Pacific coastline of South America, in the Atacama Desert and in the westernmost Central Andes, compared to the rain water of March 2015, stream water of March-April 2015, and rain water of 9 August 2015. Shown as lines are the Global Mean Water Line $\left(\delta^{2} \mathrm{H}=8 \delta^{18} \mathrm{O}+10\right)(\mathrm{GMWL})(\mathrm{Craig}, 1961$; Rozanski et al., 1993) and the Eastern Cordillera Mean Water Line $\left(\delta^{2} \mathrm{H}=8.4 \delta^{18} \mathrm{O}+15.9\right)$ (ECMWL), an example of eastern-sourced precipitation in a region immediately east of the study area (Fig. 2A box labeled "R"; Rohrmann et al. (2014)). A. Shown as circles and triangles are monthly means of Global Network of Isotopes in Precipitation (GNIP) data for Pacific coastal rains of equatorial and mid-latitude South America. Squares indicate the isotopic composition of water from springs whose recharge areas are the coastal mountains (Herrera and Custodio, 2014); B. Published northern Chilean summer season rain data for $19^{\circ}$ to $30^{\circ} \mathrm{S}$, distinguished by location on the western slope of the Andes or across an orographic divide in the western part of the internally-drained Altiplano plateau. Precipitation data correspond mostly to high elevation areas in climate zone I where mean annual precipitation exceeds $50 \mathrm{~mm}$ per year (Fig. 2B). The western slope data from Fritz et al. (1981) and Aravena et al. (1999) are for widely dispersed stations between $19-21^{\circ} \mathrm{S}$ at elevations spanning 2,380 $\mathrm{m}$ a.s.1. to 4,150 $\mathrm{m}$ a.s.1. These are summer season (November through April) amount-weighted averages for 1974 and 1975 (Fritz et al., 1981) and 1984, 1985 and 1986 (Aravena et al., 1999). The western slope data from Burgener et al. (2016) are for weighted averages of January 2013 precipitation for stations along an elevation profile (40-3,100 $\mathrm{m}$ a.s.1.) at $30^{\circ} \mathrm{S}$. The Altiplano region data are from four sources. Amount-weighted averages for summer seasons of 1973, 1974 and 1975 are from Fritz et al. (1981) and for 1984, 1985 and 1986 from Aravena et al. (1999). Those sources report locations between 19-21 ${ }^{\circ} \mathrm{S}$ at elevations between 3,720 $\mathrm{m}$ a.s.1. and 4,350 m a.s.1. Uribe et al. (2015) presented monthly amount-weighted averages for October 2010, March 2011, and November 2011 for three locations in the Salar de Huasco basin $\left(20.2^{\circ} \mathrm{S}, 68.8^{\circ} \mathrm{W}\right)$. Chaffaut $(1998)$ presented monthly mean data for a single site at $23.36^{\circ} \mathrm{S}, 67.42^{\circ} \mathrm{W}$, elevation $4,400 \mathrm{~m}$ a.s.l. corresponding to summer seasons (October through April) between October 1994 and February 1997. Box with gray background shows the range plotted in (A).

Chaffaut, 1998; Aravena et al., 1999; Uribe et al., 2015). Over the eastern Andes, precipitation at low elevations has $\delta^{18} \mathrm{O}$ of -2 to $-8 \%$ o but $\delta^{18} \mathrm{O}$ becomes depleted toward the west as vapor is lifted across the Eastern Cordillera of the Andes (Fig. 4) (Fiorella et al., 2015; Gonfiantini et al., 2001; Rohrmann et al., 2014). The dominant Altiplano summer rain has $\delta^{18} \mathrm{O}$ values of $-8 \%$ o to $-15 \%$. Published isotopic 

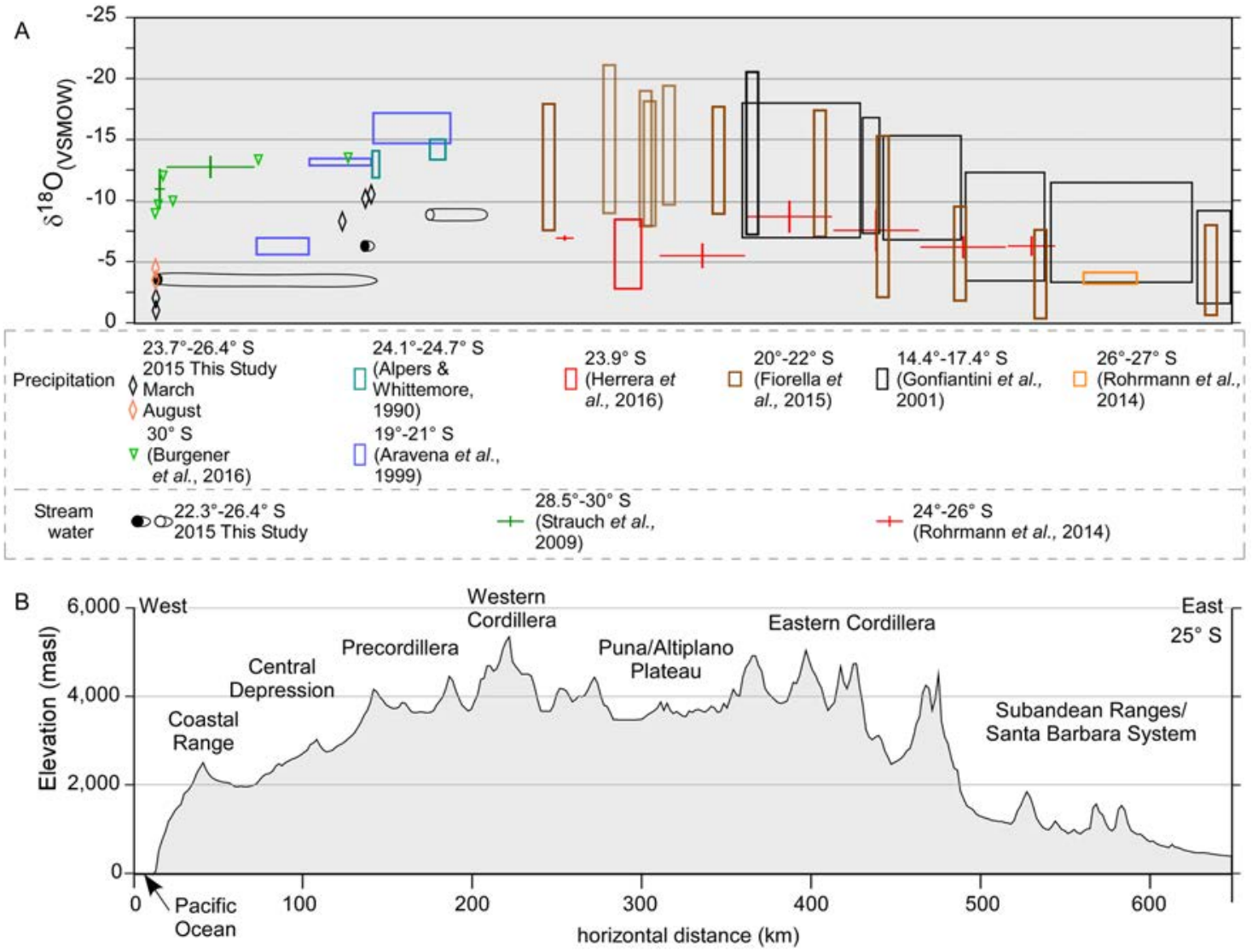

FIG. 4. A. Published $\delta^{18} \mathrm{O}$ of environmental waters for west-central South America and for the March 2015 event are compared to B topography at $25^{\circ} \mathrm{S}$. Although Andean topography varies along the strike, there are fundamental topographic features that persist and that strongly influence the movement across the Andes of water vapor-bearing air parcels. A. the horizontal lengths of lines or boxes represent bins of sampled locations. Precipitation data from Herrera et al. (2016) (red box) and Alpers and Whittemore (1990) (greenish-blue boxes) and stream data from Rohrmann et al. (2014) (red lines) are located within or near $24^{\circ}-26^{\circ} \mathrm{S}$ and are placed on the $25^{\circ} \mathrm{S}$ profile based strictly on elevation. For most data collected at greater distances from the $25^{\circ} \mathrm{S}$ profile, data were binned by altitude (usually $1,000 \mathrm{~m}$ ) and positioned on the $25^{\circ} \mathrm{S}$ profile relative to topographic barriers encountered by air masses. Fiorella et al. (2015) data are shown as individual stations; light brown boxes correspond to sampling stations located north of $20^{\circ} \mathrm{S}$, where the Altiplano plateau is much less arid than in comparable locations to the south. For all data except Burgener et al. (2016) the box height or vertical line height shows 1 standard deviation above and below the average. Burgener et al. (their table S1; 2016) (triangles) reported only amount-weighted means for precipitation during 2013 and 2014. For Gonfiantini et al. (2001) data, averages are for stations in two transects but standard deviation is for monthly data from a subset of the stations. Summer rain in the Puna plateau (red box) is anomalous to the trends on the east and west Andean flanks, possibly due to local water vapor sources, strong convection during precipitation, and below-cloud evaporation (Rohrmann et al., 2014).

data for rain in Chile south of the study area reveal moderately depleted coastal rain $(-4 \%$ to $-10 \%$; Fig. 3A) and progressive depletion at increasing elevations (Fig. 4) (Burgener et al., 2016). These characteristic isotopic values for locations along the principal water vapor paths to the Atacama Desert (Fig. 2A) lead to the expectation that precipitation in the hyperarid region should be moderately to strongly depleted at all elevations, perhaps $\delta^{18} \mathrm{O}$ of $-10 \%$ to $-15 \%$. These hypothetical values are similar to the winter precipitation within the study area (Alpers and Whittemore, 1990) and in the slightly less arid high elevation mountains $>450 \mathrm{~km}$ to the north of our study area (Fritz et al., 1981; Aravena et al., 1999). Some 
summer precipitation $450-700 \mathrm{~km}$ to the north of our study area at elevations between 2,380-3,360 $\mathrm{m}$ a.s.1. defies this expectation (Fig. 4A) (Aravena et al., 1999) and is discussed later.

\section{Materials and methods}

Five rainwater samples from the March, 2015, precipitation event were obtained from containers designed to retrieve and store precipitation. Locations and sampling dates of two samples collected near the coast in the city of Antofagasta and three in the Andean foothills are shown in figure $2 b$ and detailed in table 2. During the precipitation event, the coastal samples were transfered to $100 \mathrm{ml}$ and $1 \mathrm{~L}$ polyethylene bottles, depending on the volume of recovered sample. The rain in the very remote Andean locations was captured in tubs adapted with a funnel and a $2.5 \mathrm{~cm}$ thick layer of pure vaseline oil to prevent evaporation. These were retrieved one week (two locations) and one month (one location) after the event (Table 2). Using a syringe the water, without vaseline, was also transfered to $100 \mathrm{ml}$ and $1 \mathrm{~L}$ polyethylene bottles. Three stream samples were collected a few days after the March 24-26, 2015 precipitation event (Table 2). Stream samples were not filtered before being sent to external laboratories for analysis. The high suspended load of the Salado River (Atacama Region) was separated by decanting the water after allowing the particles to settle. All sample bottles were completely filled, capped tightly, and the cap then taped to prevent evaporation until analysis. The samples were stored in a refrigerator at $4{ }^{\circ} \mathrm{C}$ before they were sent to the laboratory for analysis. Two rain samples were collected following the same collection standards at the same coastal location during August 2015, to provide a basis for comparison to a more ordinary precipitation event.

The stable isotope compositions of most water samples were analyzed at the Environmental Isotope Laboratory from the University of Arizona; two stream samples were analyzed by the Cornell University Stable Isotope Laboratory. At Arizona, measurement was done with a gas-source isotope ratio mass spectrometer (Finnigan Delta S). For hydrogen, samples were reacted at $750{ }^{\circ} \mathrm{C}$ with $\mathrm{Cr}$ metal using a Finnigan H/Device coupled to the mass spectrometer. For oxygen, samples were equilibrated with $\mathrm{CO}_{2}$ gas at approximately $15{ }^{\circ} \mathrm{C}$ in an automated equilibration device coupled to

TABLE 2. ISOTOPIC VALUES OF $\delta^{18}$ O AND $\delta^{2} H$ (IN UNITS OF \%) AND EXCESS DEUTERIUM (d ${ }_{\mathrm{xS}}$ ) FOR WATER SAMPLES CORRESPONDING TO MARCH 2015 REGIONAL PRECIPITATION EVENT AND AUGUST 2015 COASTAL PRECIPITATION EVENT.

\begin{tabular}{|c|c|c|c|c|c|c|c|}
\hline & Latitude & Longitude & Altitude (m) & $\begin{array}{l}\text { Date sampled } \\
(\mathrm{d} / \mathrm{m} / \mathbf{y})\end{array}$ & $\delta^{18} \mathrm{O}$ & $\delta^{2} \mathbf{H}$ & $d_{x s}$ \\
\hline Antofa rain 1 & -23.7035 & -70.414615 & 100 & $25 / 3 / 15$ & -1.2 & -3 & 6.6 \\
\hline Antofa rain 2 & -23.7035 & -70.414615 & 100 & $25 / 3 / 15$ & -2.2 & -7 & 10.6 \\
\hline Chépica rain & -24.9856 & -69.3189 & 2,939 & $5 / 4 / 15$ & -8.4 & -52 & 15.2 \\
\hline Vientos Inferior rain & -25.0802 & -69.2468 & 3,641 & $5 / 4 / 15$ & -10.2 & -65 & 16.6 \\
\hline Vientos Superior rain & -25.0925 & -69.2261 & 3,962 & $6 / 5 / 15$ & -10.6 & -67.5 & 17.3 \\
\hline Los Vientos stream & -25.0747 & -69.2514 & 3,580 & $5 / 4 / 15$ & -6.4 & -53 & -1.8 \\
\hline $\begin{array}{l}\text { Salado River east of } \\
\text { Chañaral (Atacama } \\
\text { Region) }\end{array}$ & -26.377 & -70.500 & 174 & $30 / 3 / 15$ & -3.55 & -36.9 & -8.5 \\
\hline $\begin{array}{l}\text { Salado River of Loa } \\
\text { system (Antofagasta } \\
\text { Region) }\end{array}$ & -22.3109 & -68.4785 & 2,666 & $29 / 3 / 15$ & -8.88 & -62 & 9.04 \\
\hline Antofa August & -23.7035 & -70.414615 & 100 & $9 / 08 / 15$ & -4.4 & -19.9 & 15.3 \\
\hline Antofa August & -23.7035 & -70.414615 & 100 & $9 / 08 / 15$ & -3.4 & -12.2 & 15.0 \\
\hline
\end{tabular}


the mass spectrometer. Standardization is based on international reference materials Vienna Standard Mean Ocean Water (VSMOW) and Standard Light Antarctic Precipitation (SLAP). The analytical uncertainty (one standard deviation) is $0.9 \%$ for $\delta^{2} \mathrm{H}$ and $0.08 \%$ for $\delta^{18} \mathrm{O}$ on the basis of repeated internal standards. At Cornell, measurement was done using an equilibration technique on a Thermo Scientific Gas Bench II coupled to a Thermo Scientific Delta $\mathrm{V}$ mass spectrometer. In the case of deuterium, $2 \% \mathrm{H}_{2}$ gas was added into the headspace and the sample was equilibrated with this $\mathrm{H}_{2}$ with the aid of a platinum Hokko bead catalyst (Shoko Co. Ltd, Japan). For this analytical run the overall standard deviation for the internal deionized water standard was $3.44 \%$ for $\delta^{2} \mathrm{H}$ and $0.18 \%$ for $\delta^{18} \mathrm{O}$. Isotope corrections were performed based on a two-point normalization (linear regression) using one in-house standard (Mauna Kea) and VSMOW.

Daily sums of liquid precipitation corresponding to 23-29 March 2015 at 114 stations in Chile and three stations in Argentina between $20^{\circ}-32^{\circ} \mathrm{S}$ were compiled (Appendix Table A1) from two Chilean government agencies, five mining companies, a commercial weather forecasting service and university-hosted weather stations. Examination of the data revealed an apparent reporting inconsistency with one public data source that limits the temporal resolution of the full data set (Appendix Table A1 note). Therefore, we report the spatial distribution of amount for a span of days that exceeds the precipitation event. Total precipitation quantities for four other stations are available (Appendix Table A1, items 35-38), three of which were rain catchers described above. The full set of station data were manually contoured (Fig. 2B) as lines of equal precipitation. Because only two of the meteorological stations captured snow (Appendix Table A2) the total precitation is under reported. The spatial coverage of snow on 27 March 2015 was traced from a MODIS satellite image (https://earthdata.nasa.gov/labs/worldview/ (last visit 16/06/2015)).

We examined the atmospheric circulation at 0000 and 1800 Coordinated Universal Time (UTC) 25 March 2015 over a region of interest greatly exceeding the region of precipitation $\left(0^{\circ}-60^{\circ} \mathrm{S}\right.$ latitude; $0^{\circ}-120^{\circ} \mathrm{W}$ longitude) (Fig. 1). Atmospheric conditions are derived from National Centers for Environmental Prediction/National Center for Atmospheric Research (NCEP/NCAR) reanalysis data (Kalnay et al., 1996).
These data are resolved to point locations spaced 2.5-degrees latitude and longitude every six hours on 17 pressure levels $(1,000 \mathrm{mb}$ through $10 \mathrm{mb})$ for geopotential height $(Z)$, temperature $(T)$ and horizontal wind components $(\mathrm{u}, \mathrm{v})$, twelve vertical levels $(1,000 \mathrm{mb}$ through $100 \mathrm{mb})$ for vertical pressure velocity (omega) and eight levels (1,000 mb through $300 \mathrm{mb}$ ) for specific humidity, from which water vapor mixing ratio and equivalent potential temperature are calculated.

Atmospheric stability was assessed with a calculation of the vertical gradient of equivalent potential temperature (theta-e). Long-term (19812010) mean values of theta-e were calculated at each grid point from the long-term mean values of temperature and water vapor mixing ratio at that grid point. The long-term mean theta-e was then subtracted from the actual theta-e to obtain theta-e anomalies. The vertical gradient of theta-e anomalies provides an assessment of the anomalous stability or instability of the environment.

To document the source of air arriving over the precipitation-event region, air parcel trajectories were calculated with the on-line web version of the HYSPLIT model (Stein et al., 2015; Rolph, 2016). HYSPLIT calculates the movement of a single Lagrangian particle according to the threedimensional mean wind field. This analysis used Global Data Assimilation System meteorological data resolved at 0.5 degrees latitude and longitude.

Neither the atmospheric stability analysis nor the air parcel trajectory analysis includes consideration of turbulence.

\section{Results}

\subsection{Precipitation distribution}

The geographic limits of heavy rain $(>30 \mathrm{~mm})$ during the 24-26 March 2015 event were near $23^{\circ} \mathrm{S}$ and $32^{\circ} \mathrm{S}$ (Fig. 2B). North of $26^{\circ} \mathrm{S}$ heavy rain spanned over $150 \mathrm{~km}$ from the Pacific to the Andean highlands. This included the core of the hyperarid Atacama Desert (zone IV, Fig. 2B). South of $26^{\circ} \mathrm{S}$, greater than $30 \mathrm{~mm}$ fell on a $50-100 \mathrm{~km}$ wide continental interior region up to about $3,400 \mathrm{~m}$ a.s.1. that lies in climate zone III (Fig. 2B) and constitutes steep Andean upland catchment basins. An elongate region of rainfall exceeding $50 \mathrm{~mm}$ extended along the Andes Mountains from $24^{\circ}$ to 
$30^{\circ} \mathrm{S}$. At higher elevations and farther east, snow from $23^{\circ} \mathrm{S}$ to $32^{\circ} \mathrm{S}$ covered $88,000 \mathrm{~km}^{2}$ (Fig. 2B); areas covered by snow may also have received rain (Wilcox et al., 2016). North of $32^{\circ} \mathrm{S}$, areas with any amount of rain but no snow totaled approximately $175,000 \mathrm{~km}^{2}$ of Chile and, based on very sparse data, about $140,000 \mathrm{~km}^{2}$ of lowland Argentina west of $66^{\circ} \mathrm{W}$ (Appendix Table A1).

\subsection{Isotopic composition of rain and runoff}

The March 2015 rain samples included a Pacific coast site and three sites close together $>115 \mathrm{~km}$ inland; the inland sites range in elevation from 2,939-3,962 m a.s.1. (Table 2). The two coastal rain samples are little displaced from Vienna Standard Mean Ocean Water (VSMOW) and differ from one another in the $\delta^{18} \mathrm{O}-\delta^{2} \mathrm{H}$ plot (Fig. 3A) along a line with a slope of 4 , considerably less than the Global Mean Water Line (GMWL). The coastal rain water was similar to rains of coastal Ecuador, and not the rains of mid-latitude coastal Chile (Fig. 3A).

The three high elevation samples have lower $\delta^{18} \mathrm{O}$ and $\delta^{2} \mathrm{H}$ than rain at the coast (Fig. 3A and $4 \mathrm{~A}$ ) and become progressively lower with increasing elevation of the rain sampling location. The excess deuterium $\left(\mathrm{d}_{\mathrm{xs}}\right)$ of coastal sites is between 7.0 and 11.2, and for inland sites between 15.0 and 17.3 (Table 2).

Of three stream samples (Fig. 2B; Table 2), those from the Salado River (Atacama Region, $26.4^{\circ} \mathrm{S}$ ) and the Los Vientos stream are considered to be dominated by the March rain because both streams had been dry beforehand. The third stream sample, the perennial Salado River (Antofagasta Region, $22.3^{\circ} \mathrm{S}$ ), is considered to be a mixture of groundwater baseflow and recent precipitation. The Los Vientos stream isotopes are consistent with the rain water in the same small drainage basin, with $\delta^{18} \mathrm{O}$ higher by $4 \%$ and $\delta^{2} \mathrm{H}$ by $13 \%$, due to evaporation as water flowed overland to the stream. The Salado River (Atacama Region), sampled at a position far downstream in a large catchment that drains the Andes, has $\delta^{18} \mathrm{O}$ intermediate between the coastal and Andean rains (Fig. 4A; Table 2). If the effect of evaporative enrichment of ${ }^{18} \mathrm{O}$ and ${ }^{2} \mathrm{H}$ in streams relative to precipitation is similar to the Los Vientos stream, the Salado (Atacama) sample indicates that run-off from rain that fell above 3,000 m a.s.1. in the Andes was the dominant streamwater source.

\subsection{Atmospheric conditions}

The key atmospheric circulation feature at 0000 UTC 25 March 2015 (local time 21:00 h, 24 March) is the "cutoff low" at middle to upper levels of the troposphere near $75^{\circ} \mathrm{W}, 30^{\circ} \mathrm{S}$ (Fig. 1). To the south is a persistent anticyclonically breaking wave in the height field near $45^{\circ} \mathrm{S}$ that caused atmospheric blocking (Barrett et al., 2016). A high content of precipitable water in the atmosphere over the eastern equatorial Pacific was a second key attribute in setting up the extreme precipitation event (Barrett et al., 2016). As a consequence of both features, upper level winds were from the northwest over the north Chilean Pacific coast and transported anomalously moist air into the region.

This air motion was confirmed by a set of backward trajectory calculations of air arriving at 0000 UTC 26 March (21:00 local time on 25 March) to positions $500 \mathrm{~m}$ above ground level at five locations (Fig. 5A). Unlike typical conditions within the southeast Pacific anticyclone, the air mass turned cyclonically. At 1800 UTC on 25 March, there was ascending air at the $600 \mathrm{mb}$ level, centered at $29^{\circ} \mathrm{S}, 70^{\circ} \mathrm{W}$, which covered the region from $25-31^{\circ} \mathrm{S}$ across which large amounts of precipitation fell (Fig. 5B). The ascent coincided with abnormally unstable air (anomalously upward-decreasing equivalent potential temperature; Fig. 5B). Consequently, water-vapor saturated air parcels (e.g., as illustrated in figure 5A) that reached the continental interior likely would have become buoyant and accelerated upwards, precipitating water as excess precipitation. The abnormal instability was due to both abnormally cold air aloft and abovenormal water vapor mixing ratios at lower levels (not shown). This situation is suitable to explain the Elqui Algarrobal rainfall intensity peak at local time 15:00 (Fig. 6).

Figure 5A illustrates that the air parcel tracks are not all parallel. Specifically, the track to the southernmost location, Elqui Algarrobo, began at the northernmost source location, offshore southern Perú, and crossed the other tracks at a higher altitude. Complexities like this are expected because air parcels which began the time interval of interest at varying locations and heights experienced differing wind strengths and directions. Ultimately the precipitation from a storm like this is the product of a complex mixture of differing paths, as well as turbulence which is not captured in these models. The isotopic 


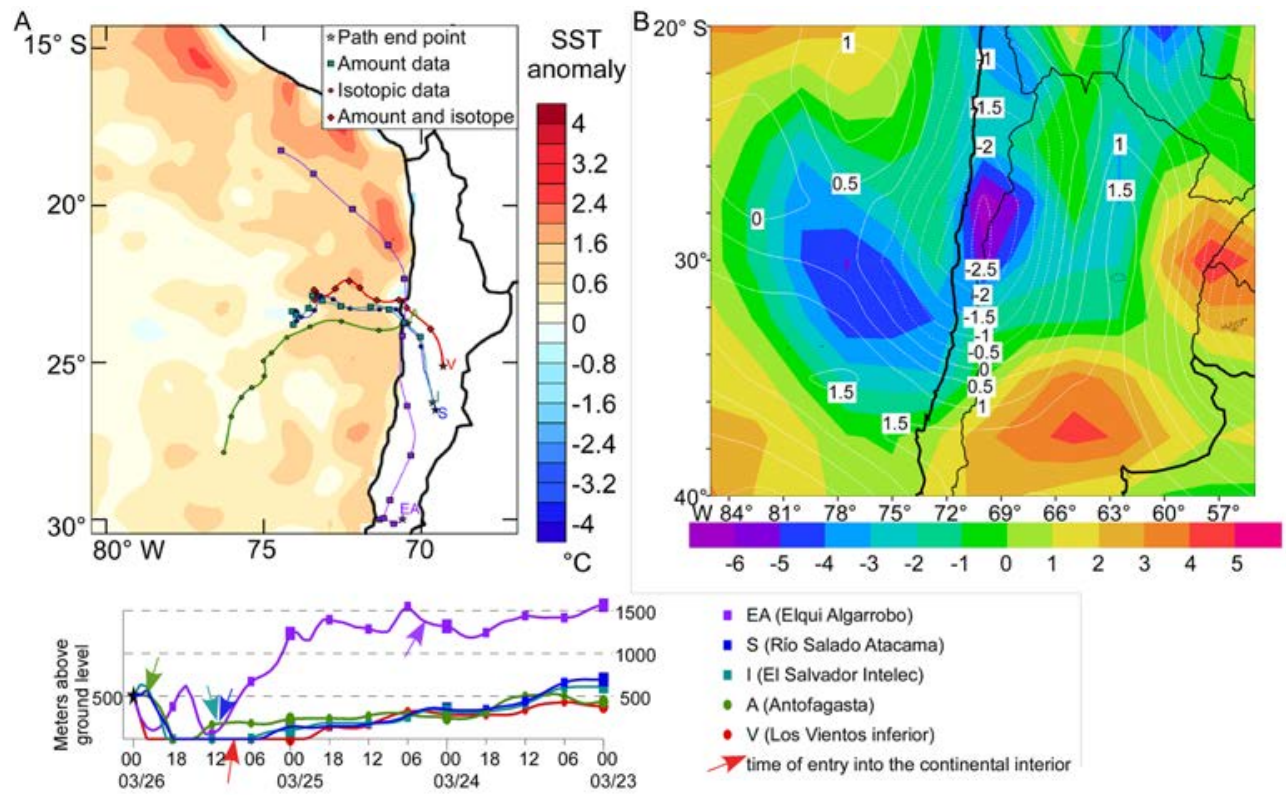

FIG. 5. A. Tracks of air parcels that arrived at five locations in the study area, and the average sea surface temperature anomalies for 23-24-25 March 2015, displayed in map (top) and cross sections (bottom). Air masses were tracked backward 72 hours prior to 0000 UTC 26 March (star) using HYSPLIT, from final locations located $500 \mathrm{~m}$ above ground surface. Progressive marks along tracks are 6-hour increments. The Sea Surface Temperature (SST) anomalies are from Bozkurt et al. (2016). End-point locations EA, I, and V have precipitation totals given in table 1. End-point locations $\mathrm{S}, \mathrm{A}, \mathrm{V}$ have precipitation isotopic data in table 2. While each air parcel was over the ocean, they share a common vertical position scale (lower plot), but once each parcel entered the continent (arrow) it crosses a unique topographic profile and its vertical position relative to the other parcels is not readily discernible in the cross sections; B. Vertical motion (white contours, microbars per second, negative values indicate upward movement) and anomalous vertical gradient of equivalent potential temperature (colors, degrees K per $100 \mathrm{mb}$ ) on the 600-mb pressure level at 1800 UTC 25 March 2015. The South American coastline and national borders are outlined in black.

composition evolves within these air masses, and it is not possible to differentiate these details based on our isotopic data.

\section{Discussion}

\subsection{Isotopic values}

The March northern Chile coastal rain O and $\mathrm{H}$ isotopic composition are very similar to those of Ecuador (Fig. 3A), with compositions that fit expectations for rain produced from rapidly evaporated ocean water (Dansgaard, 1964). This result is consistent with humid air that traveled from the tropical to subtropical eastern Pacific Ocean off the coasts of Perú and northern Chile under conditions $1-2{ }^{\circ} \mathrm{C}$ warmer than normal, as suggested by the air parcel tracks (Fig. 5A).

The $\delta^{18} \mathrm{O}$ and $\delta^{2} \mathrm{H}$ values of inland sites remain close to the Global Mean Water Line, which is consistent with little evaporative loss either as the rain fell or from the samplers. Consequently, we interpret that these samples provide robust data for air mass interpretation. The pattern of decreasing $\delta^{18} \mathrm{O}$ and $\delta^{2} \mathrm{H}$ values away from the coast and with increasing elevation in combination with the changes in water vapor saturation and wind directions point unequivocally toward the Pacific Ocean as the only significant source of the precipitation. The advection of moist subtropical to tropical eastern Pacific air (Barrett et al., 2016) and its rise across the Coastal Cordillera and then the Andes Mountains triggered the instability (Fig. 5B) that resulted in prolonged and widespread rain and snow (Fig. 2B).

The only published precipitation isotope data close to our samples from March 2015 are for winter season precipitation. Snow and rain collected during June 1984 had much lower mean $\delta^{18} \mathrm{O}$ and $\delta^{2} \mathrm{H}$ values of $-13.8 \%$ and $-92.8 \%$, respectively (Alpers and Whittemore, 1990). Further to the south at $30^{\circ} \mathrm{S}$, 


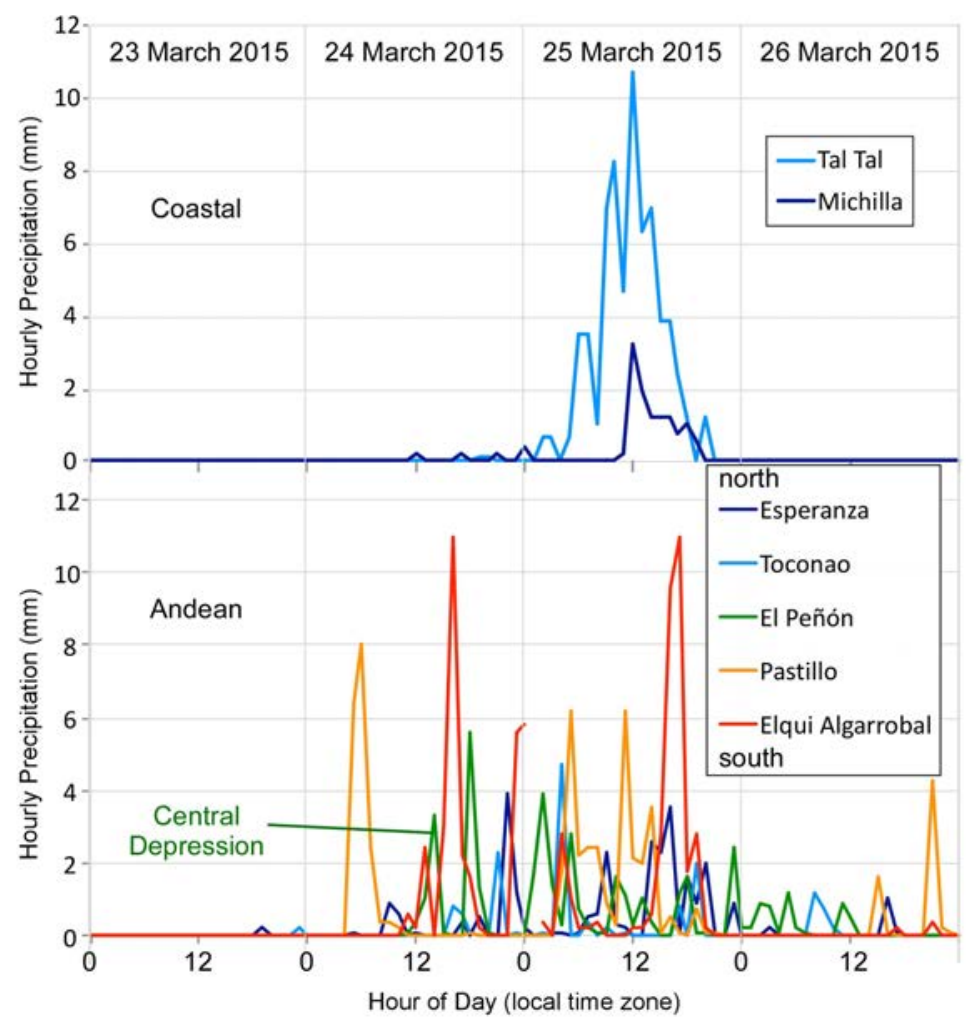

FIG. 6. Hourly precipitation amounts during 23-26 March 2015 for A. Coastal locations, and B. Interior locations. Appendix Table A1 lists sources for the hourly data, using sources with reliable dates. Michila and TalTal (Campbell) are located at $22 \mathrm{~m}$ a.s.1. and 37 m a.s.1., respectively. Elqui Algarrobal, Pastillo, El Peñón, Esperanza and Toconao are located at 760, 1,151, 1,840, 2,266, and 2,495 m a.s.1., respectively. With reference to the Chilean summer time zone (UTC-03 for March 2015), the majority of rain fell at coastal stations in the middle hours of 25 March. For most eastern stations significant rain began by mid-day 24 March and persisted through 26 March.

amount-weighted $\delta^{18} \mathrm{O}$ and $\delta^{2} \mathrm{H}$ available for primarily winter precipitation events (Table $\mathrm{S} 1$ of Burgener $e t$ al., 2016) are also much lower than for the March 2015 event. At low elevations from the coast to $1,300 \mathrm{~m}$ a.s.1., values of $\delta^{18} \mathrm{O}$ ranged between $-9.0 \%$ and $-12.3 \%$ and $\delta^{2} \mathrm{H}$ between $-64.9 \%$ and $-91.2 \%$. At high elevations (2,100-3,100 m a.s.1.), values of $\delta^{18} \mathrm{O}$ ranged between -13.5 to $-13.6 \%$ and $\delta^{2} \mathrm{H}$ between $-104.9 \%$ and $-100.3 \%$. In the Altiplano plateau outside the area of rain in March 2015, the variability is sufficient that those rains overlap with the inland March 2015 rain samples (Fig. 4) (Gonfiantini et al., 2001; Fiorella et al., 2015; Herrera et al., 2016).

In comparison, Chilean rain data at locations $>450 \mathrm{~km}$ to the north of our study area (Fritz et al., 1981; Aravena et al., 1999) revealed that amountweighted means of $\delta^{18} \mathrm{O}$ of Andean precipitation varied during summer months (1973-1975; 1984-1986) between $-4.5 \%$ to $-20.2 \%$, and rare rains in winter (June) 1984 between $-11.1 \%$ to $-12.5 \%$, with an unusually strong dependence upon elevation (Fig. 4). For comparable elevations, the March 2015 samples were isotopically less depleted (Fig. 4). However, examined in detail, summer precipitation at elevations of 2,000-3,000 $\mathrm{m}$ a.s.l. was much less depleted than same-day precipitation at altitudes greater than $3,000 \mathrm{~m}$ (Aravena et al., 1999). Aravena et al. (1999) noted that these low-elevation summer values $\left(e . g ., \delta^{18} \mathrm{O}\right.$ -4 to $-7 \%$ ) cannot be explained by a model in which water vapor is derived from the east and crosses the Andes (Fig. 2A). Consequently, Aravena et al. (1999) suggested that some summer storms driven by eastern-sourced upper air masses simultaneously drew in low-altitude tropical Pacific moisture by dynamics not captured in coarse grid meteorological analyses. The much larger scale March 2015 synoptic 
storm system delivered eastern equatorial Pacific water vapor of similar isotopic values.

Despite proximity, the isotopic composition of the Salado River (Atacama Region) stream water in March 2015 is not comparable to water from streams located between $28.5^{\circ}-31^{\circ} \mathrm{S}$ sampled in November 2006 (Fig. 4) (Strauch et al., 2009). Those springtime $2006 \delta^{18} \mathrm{O}$ values (mean $-12.8 \%$ ) are significantly lower than the March 2015 stream, and consistent with the isotopically depleted precipitation that more frequently falls on the Andes in winter (Fig. 4) (Burgener et al., 2016).

\subsection{Comparison of the March 2015 extreme event to common precipitation scenarios}

Climatological analyses have shown that all documented modern precipitation events of significance in coastal regions of northern Chile were associated with atmospheric wave disturbances that move generally eastward across the Pacific Ocean at mid-latitudes (Vargas et al., 2006). The March 2015 event shared this commonality with prior precipitation events. However, the typical major precipitation event of coastal northern Chile occurs during the winter season of an El Niño event, not in the late summer. Vargas et al. $(2000,2006)$ determined that rainfalls in Antofagasta city strong enough to cause significant flooding occurred in May (1982), June (1940, 1991), July (1925, 1940, 1987) and August $(1930,1982)$. In those cases, the intensity of rainfall has been cited as a key feature which led to the development of landslides along the Coastal Escarpment (20-40 mm per 3-hour-period) (Hauser, 1997; Vargas et al., 2000, 2006). The March 2015 event caused stream run-off floods which caused great damage to coastal cities (e.g., Chañaral), but produced much less landsliding along the Coastal Escarpment than typical intense rain events.

As the 2015 El Niño event advanced, a second significant precipitation event was generated during early August. From August 8-11 a coastal strip of Chile north of $26^{\circ} \mathrm{S}$ received up to $29.4 \mathrm{~mm}$ of rain. During the same interval, interior regions recorded little rain and the snow on the high Andes (Fig. 7A, $22^{\circ}$ to $26^{\circ} \mathrm{S}$ ) was thin enough to fade from the daily satellite images within a few days. These rains in the hyperarid Atacama Desert occurred simultaneously with much more widespread cold-front related precipitation which impacted the semi-arid to arid parts of Chile, such as the Elqui valley. North of $25^{\circ} \mathrm{S}$ the August 2015 intense rain focused on the steeply inclined western slope of the Coastal Cordillera, where it generated mudslides that caused deaths in Tocopilla and significant property loss. That August 2015 event fits well the generalizations given by Vargas et al. $(2000,2006)$ for precipitation events during prior El Niño events: it occurred during the winter and it was intense only in a narrow strip near the Pacific coast.

Rain water sampled in Antofagasta city near the coast on August 9, 2015 (Table 2) was isotopically depleted by $-2 \%$ for $\delta^{18} \mathrm{O}(-3.4$ and $-4.4 \%$ ) and $-11 \%$ for $\delta^{2} \mathrm{H}$ (-12.2 and -19.9\%) compared to the March 2015 rain. The August data indicate a Pacific water vapor source as inferred from atmospheric circulation during the storm, but from a latitude further south which is more typical of rain for northern Chile (Fig. 3). This is in contrast to the low latitude Pacific water vapor source for March 2015 precipitation.

Another significant winter season precipitation event June 6-7, 2017 brought up to $40 \mathrm{~mm}$ of rain to part of the hyperarid Atacama Desert and regionally extensive snow above about 2,700 meters elevation above sea level (Fig. 7B). This event is not reported to be related to El Niño conditions nor to anomalous warmth in the eastern equatorial Pacific. The June 2017 event fits well the cold-front scenario of winter season precipitation described by Vuille and Ammann (1997). It had larger impact on the Atacama Desert than most cold fronts: less than $20 \%$ of all winter cold fronts in years 1984, 1986, and 1990-1993 (Vuille and Ammann, 1997) extended as far north as the June 2017 snow cover (Fig. 7B).

\subsection{Geological differences among March 2015 precipitation scenario and other scenarios}

Comparison of the March 2015, August 2015, and July 2017 precipitation events reveals that the three hydrometeorological scenarios have multiple differences that may be recorded in geological materials or landforms. Relative to the typical El Niño Southern Oscillation (ENSO)-related August 2015 event, the March 2015 scenario generated a much larger regional footprint and volume of precipitation and, for interior high elevation areas, much faster surface run-off. Therefore, across the core of the hyperarid Atacama Desert, the March 2015 scenario would have greater geomorphological consequences 


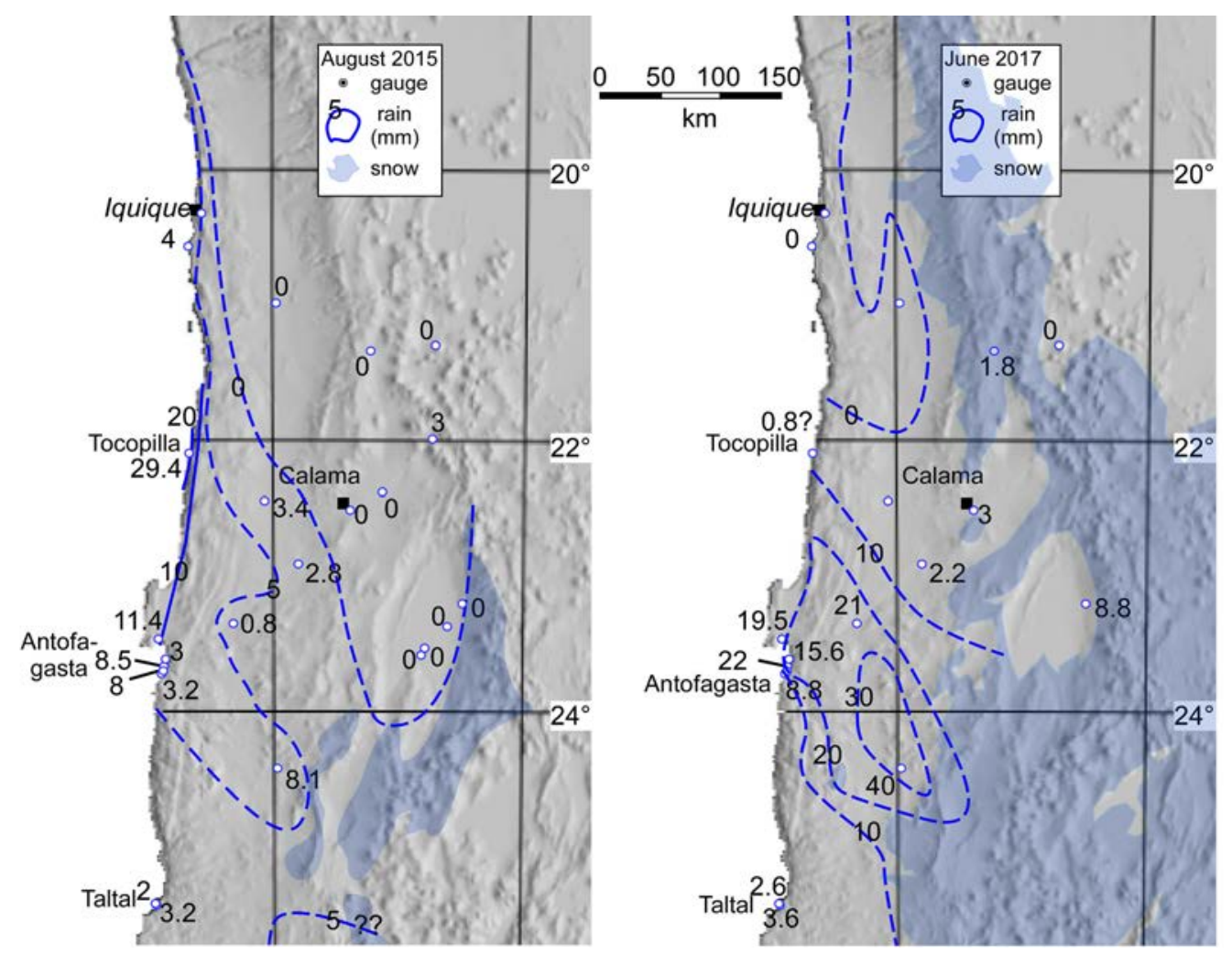

FIG. 7. Cumulative rainfall (mm) during two winter season precipitation events in the hyperarid sector of the Atacama Desert. Contour lines of equal liquid precipitation amounts based on gauge data (shown) and radar-based rain amount forecasts (http://www.star. nesdis.noaa.gov/smcd/emb/ff/HE_SA_24Hour.php (last visit 14/04/2015)). A. Cumulative amounts for the days 8-11 August 2015. Note the sharp spatial gradient of rain: large amounts fell along the Coastal Escarpment but only trace amounts occurred inland except SE of Antofagasta city. Snow associated with this event was thin enough to have melted from most highland regions within two days; B. Cumulative rainfall and snow distribution 6-7 June 2017. A region of heavy rain extended eastward across the hyperarid core of the Central Depression southeast of Antofagasta city, and snow was widespread in the Andes.

than would the August 2015 scenario. The isotopic record that might be preserved in plant waxes or groundwater would differ only subtly between the two situations, with slightly more enriched oxygen and hydrogen isotopic values for the March 2015 scenario. Whereas rain intensity at Taltal reached approximately $20 \mathrm{~mm}$ per-3-hours during the March 2015 event (Fig. 6), which is the lower limit in the range of intensities shown to cause Coastal Escarpment mudslides near Antofagasta (Vargas et al., 2000, 2006), mudslides from the Coastal Escarpment were not a major consequence. Paleo-mudslide deposits along the toe of the Coastal Escarpment would be more likely products of the August 2015 scenario than the March 2015 scenario.

The June 2017 cold front winter storm produced more widespread precipitation in the hyperarid
Atacama Desert than did the August 2015 event and less widespread than during the March 2015 extreme event (Fig. 7). Like most winter season cold fronts and cut-off lows, the temperature-controlled elevation of change from rain to snow was low and thus runoff from the Andes Mountains was delayed and diminished. Consequently, less regionally extensive erosion in ephemeral stream beds would be expected compared to the March 2015 event, a hypothesis borne out by field observations in June 2017.

\subsection{Paleoclimate implications}

The March 2015 precipitation event offers criteria for use in paleoclimate, groundwater hydrology, and archeological studies, with which to elucidate whether it is a scenario that was significant during 
intervals of wetter climate in the past. Each discipline looks to modern climate to explain the factors responsible for past climate states but conditions in late March 2015 had not been encountered since records and observations started. Consequently, this hydrometeorological scenario has not been considered among the explanations for millennial-duration late Pleistocene to Holocene wet paleoclimate periods.

In climate zone I, in zone III north of $26^{\circ} \mathrm{S}$, and along the eastern margin of the hyperarid Atacama Desert (zone IV), between $18 \mathrm{ka}$ and 9 ka B.P. prolonged intervals of wetter climate occurred in the Andes Mountains above $2000 \mathrm{~m}$ a.s.1. (Grosjean et al., 2001; Latorre et al., 2002, 2006; Rech et al., 2002; Placzek et al., 2009; Nester et al., 2007; Quade et al., 2008; Díaz et al., 2012; Gayó et al., 2012), referred to as the Central Andean Pluvial Event (CAPE) (Fig. 8). Contemporaneous groundwater-fed wetlands are reported in the Coastal Cordillera (Díaz et al., 2012). South of $25^{\circ} \mathrm{S}$, wetter conditions in the Andean highlands during the Late Glacial Maximum, approximately 28-18 Ka B.P., are recognized (Lamy et al., 1998; Lamy et al., 2000; Maldonado et al., 2005; Díaz et $a l ., 2012)$. Usually these paleoclimate intervals are assumed to be explained by one of three conditions known to have been modes of interannual variability during the $20^{\text {th }}$ century (e.g., Lamy et al., 1998, 2000; Latorre et al., 2002, 2006; Maldonado et al., 2005; Quade et al., 2008; Garreaud et al., 2009; Placzek et al., 2009; Gayó et al., 2012; Díaz et al., 2012; Sáez et al., 2016). Two of these modes have been associated with enhanced precipitation on the margins of the Atacama Desert: the increased frequency of northward incursion of Pacific-sourced winter rains from mid-latitude weather systems, and more frequent westward spill-over of summer rains from Amazon-sourced air masses. The third mode, greater summer season supply of water vapor from the Argentine plains southeast of the Atacama Desert (Vuille and Keimig, 2004), is discussed in depth below. Not included among the paleoclimate options was the March 2015 scenario.

Because of location and season, a comparison of the March 2015 precipitation event to the scenarios for precipitation south of $22^{\circ} \mathrm{S}$ in the Central Andes evaluated by Vuille and Keimig (2004) is relevant. Vuille and Keimig (2004) demonstrated that summer precipitation during wetter-than-average years between 1983 to 1999 was commonly anti-phased north and south of a latitudinal limit near $22^{\circ} \mathrm{S}$. They compared summer season rain station data for sparsely distributed Peruvian, Bolivian, Argentine and Chilean sites to satellite information indicative of convective cloud activity and demonstrated that the spatially extensive satellite data could be used as a precipitation proxy. The region north of $22^{\circ} \mathrm{S}$ behaves as described by earlier studies (Aceituno 1988; Rutllant and Fuenzalida, 1991; Houston and Hartley, 2003; Garreaud et al., 2009) (Fig. 2A), whereby Amazon lowland water vapor is transported westward to the Andean crest and western slope of the Andes whenever the balance between the dominant westerly winds and easterly flow shifts to allow westward translation of the eastern air mass. However, south of $22^{\circ} \mathrm{S}$ the satellite rain proxy data across the whole width of the Andes and corresponding atmospheric data suggest that summer rain is most likely when two anomalous conditions coincide: the low-level (below $700 \mathrm{hPa}$ ) air mass over the Argentine Pampas has anomalously high water vapor, and there exists easterly flow aloft (above the $500 \mathrm{hPa}$ pressure level) (for reference, the crest of the Andes Mountains occurs at approximately the $600 \mathrm{hPa}$ air pressure level). That situation was met (summers of 1983-1998) when the center of an upper level anticyclone was located near $37^{\circ} \mathrm{S}$ over the mid-latitude Argentine Pampas, which drove high altitude easterly winds on the north side of that anticyclone.

This scenario does not fit the 24-26 March 2015 precipitation event. Consistent with the Vuille and Keimig (2004) scenario, there was an area of enhanced precipitable water vapor over the Pampas near $28^{\circ}$ $30^{\circ} \mathrm{S}$ on the first two days of the rain event (Bozkurt et al. 2016). Furthermore, there was an anticyclonic high over southern Argentina (onshore center near $46^{\circ} \mathrm{S}$ ), which played a key role by setting up blocking that dictated the unusual path across the Andes taken by the equatorial Pacific air mass (Fig. 1 and Barrett et al., 2016). However, the pressure field to the north of that anticyclone resulted in a strong westerly flow at $600 \mathrm{mb}$, allowing Pacific-sourced water vapor to cross the crest of the Andes and enter the eastern lowlands (Fig. 8), not the more commonly assumed reverse direction of flow.

Several authors have called upon the anti-phasing of modern precipitation in the Central Andes (Vuille and Keimig, 2004) as an explanation for variability 


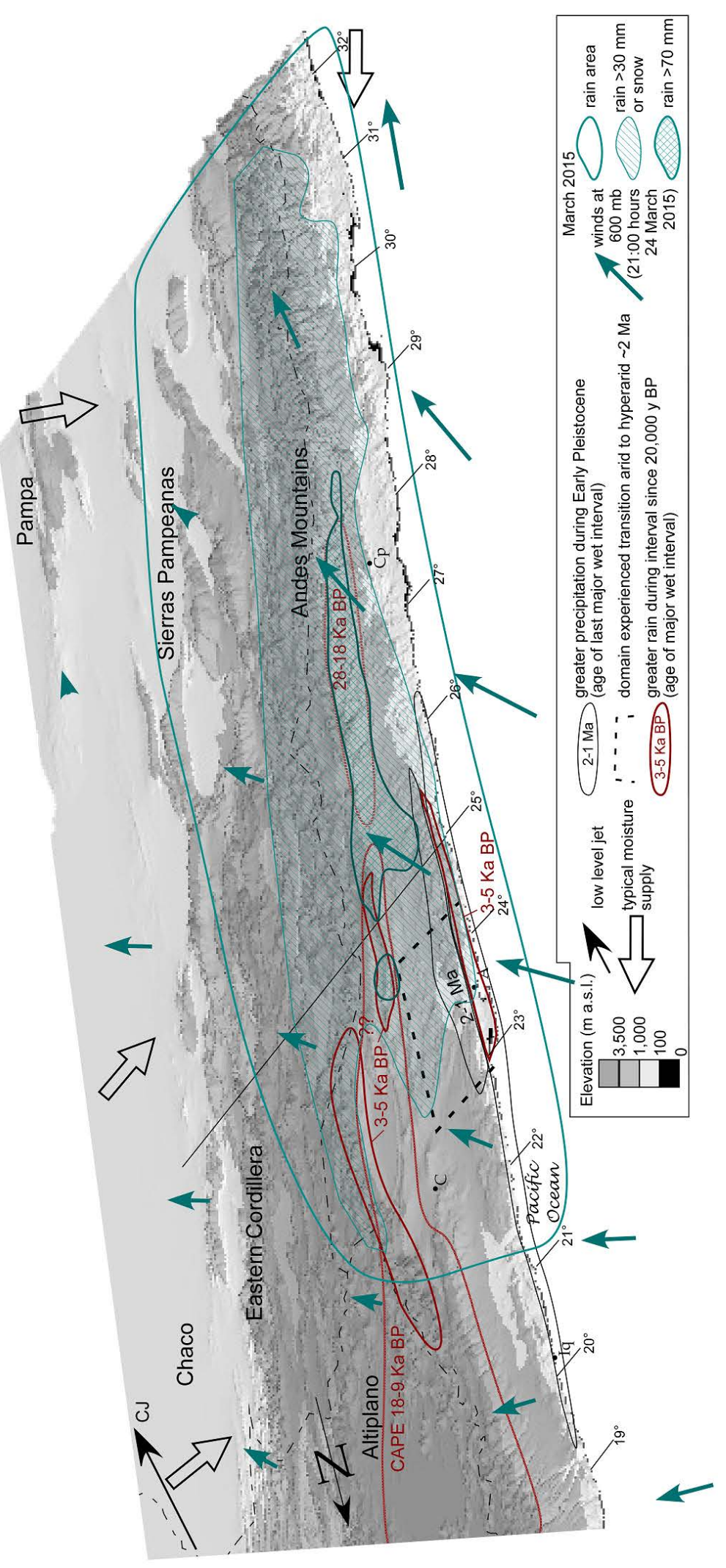

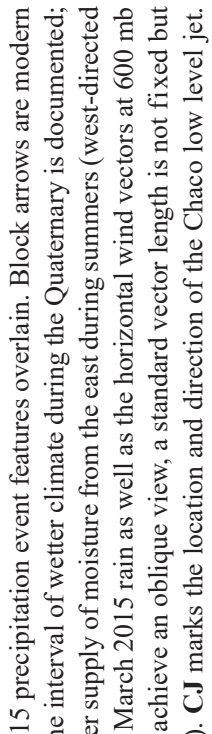

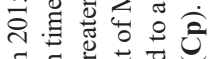

क्ष

击.

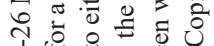

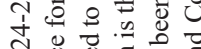

フै

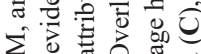

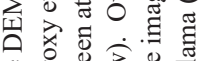

药

형 矛至比

칠 氜

ธี

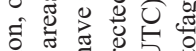

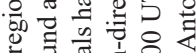

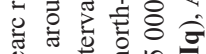

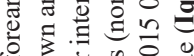

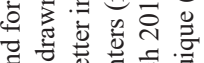

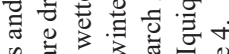

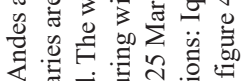

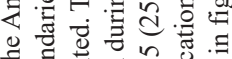

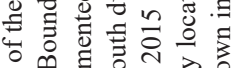

号穴言

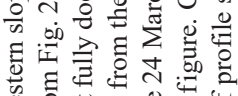

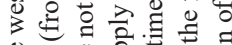

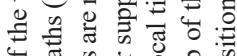

पूँ

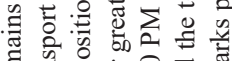

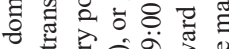

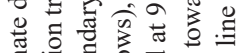

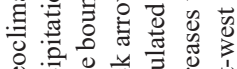

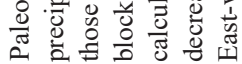

نํ. 
of the time-space pattern displayed by CAPE. For example, whereas a first CAPE stage (18-14.2 ka B.P.) was widespread north of $26^{\circ} \mathrm{S}$ (Fig. 8), at most locations south of $23^{\circ} \mathrm{S}$ the second stage (13.89.7 ka B.P.) was wetter (Gayó et al., 2012). The general spatial similarity between millennial-scale anti-phasing and the interannual anti-phasing led to the hypothesis that intervals like the second CAPE stage represent times of enhanced water vapor delivery to the southern Atacama Desert from the Argentine plains southeast of the Atacama (Placzek et al., 2009; Quade et al., 2008; Gayó et al., 2012; Sáez et al., 2016). An alternative explanation that should be evaluated is that enhanced frequency of conditions like those of late March 2015 was responsible for CAPE 2.

Times of wetter conditions documented in the central lowland $(<3,000 \mathrm{~m}$ a.s.l.) core of the Atacama Desert (zone I) also merit reexamination in search of better understanding of the precipitation sources for the CAPE and Holocene vegetation. As summarized by Díaz et al. (2012), in the lowland region water supplies in excess of $20^{\text {th }}$ century quantities on which paleo-plant growth depended might have come from four sources: i) local rainfall at the site where the paleo-vegetation grew; ii) increases in fog intensity or extent; iii) extreme rainfall at high elevations that caused flash floods in the hyperarid lowlands; iv) higher groundwater levels feeding perennial streams and wetlands in the lowlands due to recharge by persistent rainfall at high elevations. Among those options, the March 2015 precipitation event provided rain water locally (situation i) as well as at high elevations (iii, iv). If frequent repetition during the $21^{\text {st }}$ century of the March 2015 conditions were to lead to the extent of environmental change recorded by paleoclimate records, then the flash-flood scenario (iii) and the groundwater recharge-discharge scenario (iv) may grow more easily differentiable. For the Late Pleistocene and Holocene sites with rodent middens as climate proxies, details of vegetation types can reveal the seasonality of precipitation and allow stream- or groundwater-fed oasis plants to be differentiated from hillslopes plants representative of local rainfall (e.g., at 3,000 $\mathrm{m}$ a.s.1., $22^{\circ} \mathrm{S}$; Latorre et al., 2006; Gayó et al., 2012). The adoption of proxies that conserve information about the water isotope variations, such as rodent teeth or plant wax, would be invaluable to further investigate the regional paleoclimate system.
An additional historical perspective on precipitation pathways may be available in groundwater. Groundwater isotopic compositions reflect a time-integrated amount-weighted average of precipitation (Aravena, 1995; West et al., 2014). In some areas of the Atacama Desert groundwater recharge continued during the latter half of the 20th century (e.g., Houston, 2007), whereas other aquifers primarily recharged hundreds to thousands of years ago (Aravena, 1995; Herrera and Custodio, 2014; Herrera et al., 2018). Within that spectrum of recharge are insights to both recent climate and paleoclimate states. For example, spring water for coastal Antofagasta province (climate zone II) of apparent mid-Holocene age (Herrera and Custodio, 2014; Herrera et al., 2018) (Fig. 3A) has $\delta^{18} \mathrm{O}$ near zero $(+0.2 \%$ to $-2.2 \%$ ), evidence that those coastal springs recharged by precipitation derived from the adjacent Pacific Ocean. That composition is much like the March 2015 rain (Fig. 3A).

The middle Holocene record deserves new consideration in light of the March 2015 extreme rain scenario. In addition to the coastal springs, rodent middens with vegetation debris of similar age ( $3.7 \mathrm{ka}$ B.P.) are reported $20 \mathrm{~km}$ inland (Díaz et al., 2012), paleo-spring deposits occur $140 \mathrm{~km}$ inland (3.14.7 ka B.P.) (Sáez et al., 2016), and paleowetlands occur $260 \mathrm{~km}$ inland (3.1-7.4 ka B.P.) (Rech et al., 2002). Collectively, these sites appear to define a region of enhanced precipitation stretching from the coast to the Andes (Fig. 8). If a discrete time interval of wet conditions did extend inland across the core of hyperarid zone IV, a reasonable interpretation would be that rains like those of March 2015 were common 3,000-5,000 years ago but not in more recent times. A similar paleoclimate history has been demonstrated for the west coast of South America farther north. Carré et al. (2014) showed that El Niño conditions began to deliver important quantities of rain to coastal Perú approximately $4.7 \mathrm{ka}$ BP, after having been suppressed between 5-7 ka BP. Nevertheless, continuity of wetter conditions from the coast to the Andes across the hyperarid Atacama Desert at $22^{\circ}-25^{\circ} \mathrm{S}$ during the same time is speculative. Both the spatial continuity of precipitation events across the Atacama Desert during the latter middle Holocene and the hypothetical linkage to warm SST conditions could be better evaluated if oxygen or hydrogen isotopic data from groundwater or middens of appropriate age become available. 
Broadly, the March 2015 storm shows a need for reconsideration of paleoclimate interpretations that are linked to ENSO phase. A connection to changed or enhanced paleo-ENSO variability has been postulated to contribute to paleoclimate variability during the last 20,000 years in climate zone IV (Vargas et al., 2006; Latorre et al., 2006). During the last century La Niña conditions have enhanced summer rainfall on the Altiplano (zone I) whereas El Niño conditions increased winter precipitation in central Chile (zone III) (Aceituno, 1988; Rutllant and Fuenzalida, 1991; Garreaud et al., 2009). For coastal northern Chile (zone II) a correlation between precipitation and El Niño conditions is positive only for winter rain along the coastline (Ortlieb, 1995; Vargas et al., 2006; Bozkurt et al., 2016). While it is reasonable that an increase in rain in any of those neighboring zones would increase the likelihood of increased rain in the core of the Atacama Desert, the case is not strong for attributing past wet intervals in zone IV to a given ENSO phase. The March 2015 rain, for summer season at the onset of an El Niño, demonstrates that preconceived notions about how ENSO might modulate rain in the hyperarid Atacama Desert should be applied judiciously to paleoclimate interpretation.

Much longer duration paleoclimate variations can also be illuminated by the March 2015 event. Amundson et al. (2012) present the history of aridity in the Atacama Desert recorded in landforms between $23^{\circ}-25^{\circ} \mathrm{S}$ (Fig. 8, box with dashed black border). The northern $100 \mathrm{~km}$ of the region of heavy rain $(>30 \mathrm{~mm})$ during the March 2015 event coincided with the Amundson et al. (2012) study area. They deduced that less arid conditions prior to circa 2 Ma corresponded to warmer SSTs in the eastern equatorial Pacific and a diminished east-west temperature gradient (a persistent El Niño state), whereas hyperarid conditions since that time corrresponded to overall cooler SSTs and an east-west gradient characteristic of La Niña conditions. Given the prominent geomorphological tranformations that resulted from that climate change, Amundson et al. (2012) drew attention to the possibility that future climate warming might increase rainfall in northern Chile. The late March 2015 conditions and consequences align well with their prediction.

The fact that the $\delta^{18} \mathrm{O}$ and $\delta^{2} \mathrm{H}$ of March 2015 rain are readily differentiated from other historical rains (Fig. 4) and are diagnostic of a tropical Pacific source should stimulate reexamination of Atacama Desert paleoclimate records. Mapping of the spatial patterns of $\delta^{18} \mathrm{O}$ and $\delta^{2} \mathrm{H}$ in paleo-precipitation proxies or of long residence-time groundwater would enable better differentiation of times and regions impacted by rain like that of March 2015.

\section{Conclusions}

From 24-26 March 2015 heavy rain fell across a very wide area of northern Chile's Atacama Desert. The driver for this rare and high-impact event was an unusual weather system that traversed the Pacific Ocean at a time that the ocean's surface water was unusually warm. Isotopic values of rain water and river samples demonstrate that the March 2015 precipitation event supplied water that was outside the isotopic range expected for the western slope of the Andes between $23^{\circ}-30^{\circ} \mathrm{S}$, and therefore similar past events should be recognizable in paleohydrological records. In combination, the stable isotopes and atmospheric conditions show that the eastern subtropical and tropical Pacific Ocean was the source of the water vapor. The conditions that produced the March 2015 rain in the hyperarid Atacama Desert had not been included among scenarios for interannual variability of modern climate states. Likewise, the March 2015 scenario was overlooked as a possibility to explain documented wetter intervals in the Atacama Desert during the late Pleistocene and Holocene. Here we show that a comparison of the spatial distribution of areas with proxies indicative of past wetter conditions to the distribution of precipitation from modern major events is one clue to the plausible water vapor source area. Nevertheless, future incorporation of isotopic evidence that could fingerprint paleo-water vapor pathways like that of March 2015 will help to disentangle spatially overlapping phenomena and improve interpretations of causation of past climate change.

\section{Acknowledgments}

This study was supported by Anillo Project ACT1203 of CONICYT (Chile). CONICYT/FONDAP Grant 15110017 (National Research Center for Integrated Natural Disaster Management) supported rapid response task forces shortly after the March and August 2015 precipitation events. The investigation was also funded by Ph.D. grants from CONICYT-PCHA/Doctorado Nacional, number 201621160152 for author C. Gamboa P. and 2015-21150951 for 
author J. Urrutia M. We are grateful to the Air Resources Laboratory of NOAA(USA) for developing HYSPLIT and providing online access. Technical assistance by staff of University of Arizona and Cornell University stable isotope laboratories is appreciated, and by R. Riquelme, H. Ramos, L. Tapia, K. Centellas, I. Del Río, M. Pulgar (Universidad Católica del Norte, Antofagasta) and J. Gironás L. (Pontifícia Universidad Católica de Chile). Reviews of an earlier draft of this paper by I. Aguirre and M. Rojas resulted in significant improvements.

\section{References}

Aceituno, P. 1988. On the functioning of the Southern Oscillation in the South American sector. Part I: Surface climate. Monthly Weather Review 116 (3): 505-524.

Alpers, C.N.; Whittemore, D.O. 1990. Hydrogeochemistry and stable isotopes of ground and surface waters from two adjacent closed basins, Atacama Desert, northern Chile. Applied Geochemistry 5 (5-6): 719-734.

Amundson, R.; Dietrich, W.; Bellugi, D.; Ewing, S.; Nishiizumi, K.; Chong, G.; Owen, J.; Finkel, R.; Heimsath, A.; Stewart, B. 2012. Geomorphologic evidence for the late Pliocene onset of hyperaridity in the Atacama Desert. Geological Society of America Bulletin 124 (7-8): 1048-1070.

Aravena, R. 1995. Isotope hydrology and geochemistry of northern Chile groundwaters. Bulletin de l'Institut Français d'Études Andines 24 (3): 495-503.

Aravena, R.; Suzuki, O.; Pena, H.; Pollastri, A.; Fuenzalida, H.; Grilli, A. 1999. Isotopic composition and origin of the precipitation in Northern Chile. Applied Geochemistry 14 (4): 411-422.

Barrett, B.S.; Campos, D.A.; Veloso, J.V.; Rondanelli, R. 2016. Extreme temperature and precipitation events in March 2015 in central and northern Chile. Journal of Geophysical Research, Atmospheres 121 (9): 4563-4580.

Bozkurt, D.; Rondanelli, R.; Garreaud, R.; Arriagada, A. 2016. Impact of Warmer Eastern Tropical Pacific SST on the March 2015 Atacama Floods. Monthly Weather Review 144 (11): 4441-4460.

Burgener, L.; Huntington, K.W.; Hoke, G.D.; Schauer, A.; Ringham, M.C.; Latorre, C.; Díaz, F.P. 2016. Variations in soil carbonate formation and seasonal bias over $>4 \mathrm{~km}$ of relief in the western Andes $\left(30^{\circ} \mathrm{S}\right)$ revealed by clumped isotope thermometry. Earth and Planetary Science Letters 441: 188-199.

Carré, M.; Sachs, J.P.; Purca, S.; Schauer, A.J.; Braconnot, P.; Falcón, R.A.; Julien, M.; Lavallée, D. 2014. Holocene history of ENSO variance and asymmetry in the eastern tropical Pacific. Science 345 (6200): 1045-1048.

Chaffaut, I. 1998. Precipitations D'Altitude, Eaux Souterraines Et Changements Climatiques De L'Altiplano Nord-Chile. Universite de Paris Sud U.F.R. Scientifique D’Orsay: 597 p. Paris.

Craig, H. 1961. Isotopic variations in meteoric waters. Science 133 (3465): 1702-1703.

Dansgaard, W. 1964. Stable isotopes in precipitation. Tellus 16 (4): 436-468.

Díaz, F.P.; Latorre, C.; Maldonado, A.; Quade, J.; Betancourt, J.L. 2012. Rodent middens reveal episodic, long-distance plant colonizations across the hyperarid Atacama Desert over the last 34,000 years. Journal of Biogeography 39 (3): 510-525.

Fiorella, R.P.; Poulsen, C.J.; Pillco-Zolá, R.S.; Barnes, J.B.; Tabor, C.R.; Ehlers, T.A. 2015. Spatiotemporal variability of modern precipitation $\delta^{18} \mathrm{O}$ in the central Andes and implications for paleoclimate and paleoaltimetry estimates. Journal of Geophysical Research, Atmospheres 120 (10): 4630-4656.

Fritz, P.; Suzuki, O.; Silva, C.; Salati, E. 1981. Isotope hydrology of groundwaters in the Pampa del Tamarugal, Chile. Journal of Hydrology 53 (1-2): 161-184.

Garreaud, R.D.; Vuille, M.; Compagnucci, R.; Marengo, J. 2009. Present-day South American climate. Palaeogeography, Palaeoclimatology, Palaeoecology 281 (3-4): 180-195.

Gayó, E.M.; Latorre, C.; Jordan, T.E.; Nester, P.L.; Estay, S.A.; Ojeda, K.F.; Santoro, C.M. 2012. Late Quaternary hydrological and ecological changes in the hyperarid core of the northern Atacama Desert $\left(\sim 21^{\circ} \mathrm{S}\right)$. EarthScience Reviews 113: 120-140.

Gonfiantini, R.; Roche, M.-A.; Olivry, J.-C.; Fontes, J.-C.; Zuppi, G.M. 2001. The altitude effect on the isotopic composition of tropical rains. Chemical Geology 181 (1): 147-167.

Grosjean, M.; van Leeuwen, J.; van der Knapp, W.; Geyh, M.; Ammann, B.; Tanner, W.; Messerli, B.; Núñez, L.; Valero-Carcés, B.; Veit, H. 2001. A 22,000 ${ }^{14} \mathrm{C}$ year BP sediment and pollen record of climate change from Laguna Miscanti $\left(23^{\circ} \mathrm{S}\right)$, northern Chile. Global and Planetary Change 28: 35-51.

Hauser, A. 1997. Los aluviones del 18 de junio de 1991 en Antofagasta: un análisis crítico, a 5 años del desastre. Servicio Nacional de Geología y Minería, Boletín 49: 1-47.

Herrera, C.; Custodio, E. 2014. Origin of waters from small springs located at the northern coast of Chile, in the vicinity of Antofagasta. Andean Geology 41 
(2): 314-341. doi: 10.5027/andgeoV41n2-a03.

Herrera, C.; Custodio, E.; Chong, G.; Lambán, L.J.; Riquelme, R.; Wilke, H.; Jódar, J.; Urrutia, J.; Urqueta, H.; Sarmiento, A. 2016. Groundwater flow in a closed basin with a saline shallow lake in a volcanic area: Laguna Tuyajto, northern Chilean Altiplano of the Andes. Science of The Total Environment 541: 303-318.

Herrera, C.; Gamboa, C.; Custodio, E.; Jordan, T.; Godfrey, L.; Jódar, J.; Luque, J.A.; Vargas, J.; Sáez, A. 2018. Groundwater origin and recharge in the hyperarid Cordillera de la Costa, Atacama Desert, northern Chile. Science of the Total Environment 624: 114-132.

Houston, J. 2007. Recharge to groundwater in the Turi Basin, northern Chile: An evaluation based on tritium and chloride mass balance techniques. Journal of Hydrology 334 (3-4): 534-544.

Houston, J.; Hartley, A.J. 2003. The central Andean west-slope rainshadow and its potential contribution to the origin of hyper-aridity in the Atacama Desert. International Journal of Climatology 23 (12): 14531464.

Jordan, T.E.; Riquelme, R.; González, G.; Herrera, C.; Godfrey, L.; Colucci, S.; Gironás León, J.; Gamboa, C.; Urrutia, J.; Tapia, L.; Centella, K.; Ramos, H. 2015. Hydrological and geological consequences of the extreme precipitation event of 24-26 March 2015. In Congreso Geológico Chileno, No 14, Conference Proceedings, No. At3Sim12_001. Sociedad Geológica de Chile: 1-4. La Serena.

Kalnay, E.; Kanamitsu, M.; Kistler, R.; Collins, W.; Deaven, D.; Gandin, L.; Iredell, M.; Saha, S.; White, G.; Woollen, J. 1996. The NCEP/NCAR 40-year reanalysis project. Bulletin of the American meteorological Society 77 (3): 437-471.

Lamy, F.; Hebbeln, D.; Wefer, G. 1998. Late Quaternary precessional cycles of terrigenous sediment input off the Norte Chico, Chile $\left(27.5^{\circ} \mathrm{S}\right)$ and palaeoclimatic implications. Palaeogeography, Palaeoclimatology, Palaeoecology 141 (3): 233-251.

Lamy, F.; Klump, J.; Hebbeln, D.; Wefer, G. 2000. Late Quaternary rapid climate change in northern Chile. Terra Nova-Oxford 12 (1): 8-13.

Latorre, C.; Betancourt, J.L.; Rylander, K.A.; Quade, J. 2002. Vegetation invasions into absolute desert: A 45,000 yr rodent midden record from the CalamaSalar de Atacama basins, northern Chile (lat $22^{\circ}-24^{\circ}$ S). Geological Society of America bulletin 114 (3): 349-366.

Latorre, C.; Betancourt, J.L.; Arroyo, M.K.T. 2006.
Late Quaternary vegetation and climate history of a perennial river canyon in the Río Salado basin $\left(22^{\circ} \mathrm{S}\right)$ of Northern Chile. Quaternary Research 65: 450-466.

Luchinger Moyano, P.A. 2013. Simulación hidrogeológica para la explotación del acuífero ubicado en la quebrada potrero grande, Región de Atacama. Memoria de título (Inédito) Thesis, Universidad de Chile : 113 p. Santiago.

Maldonado, A.; Betancourt, J.L.; Latorre, C.; Villagran, C. 2005. Pollen analyses from a 50 000-yr rodent midden series in the southern Atacama Desert $\left(25^{\circ}\right.$ $30^{\circ}$ S). Journal of Quaternary Science 20 (5): 493-507.

Nester, P.L.; Gayó, E.; Latorre, C.; Jordan, T.E.; Blanco, N. 2007. Perennial stream discharge in the hyperarid Atacama Desert of northern Chile during the latest Pleistocene. Proceedings of the National Academy of Sciences of the United States of America 104 (50): 19724-19729.

Ortlieb, L. 1995. Eventos El Niño y episodios lluviosos en el Desierto de Atacama: El registro de los últimos dos siglos. Bulletin de 1'Institut Français d'études Andines 24 (3): 519-537.

Placzek, C.; Quade, J.; Betancourt, J.L.; Patchett, P.J.; Rech, J.A.; Latorre, C.; Matmon, A.; Holmgren, C.; English, N.B. 2009. Climate in the dry central Andes over geologic, millennial, and interannual timescales. Annals of the Missouri Botanical Garden 96 (3): 386-397.

Quade, J.; Rech, J.A.; Betancourt, J.L.; Latorre, C.; Quade, B.; Rylander, K.A.; Fisher, T. 2008. Paleowetlands and regional climate change in the central Atacama Desert, northern Chile. Quaternary Research 69 (3): 343-360.

Rech, J.A.; Quade, J.; Betancourt, J.L. 2002. Late Quaternary paleohydrology of the central Atacama Desert (lat $22^{\circ}-24^{\circ} \mathrm{S}$ ), Chile. Geological Society of America Bulletin 114 (3): 334-348.

Rohrmann, A.; Strecker, M.R.; Bookhagen, B.; Mulch, A.; Sachse, D.; Pingel, H.; Alonso, R.N.; Schildgen, T.F.; Montero, C. 2014. Can stable isotopes ride out the storms? The role of convection for water isotopes in models, records, and paleoaltimetry studies in the central Andes. Earth and Planetary Science Letters 407: 187-195.

Rolph, G.D. 2016. Real-time Environmental Applications and Display sYstem (READY). Website http://ready. arl.noaa.gov (last visit 18/12/2017), NOAA Air Resources Laboratory, Silver Spring, MD.

Rozanski, K.; Araguás-Araguás, L.; Gonfiantini, R. 1993. Isotopic patterns in modern global precipitation. Climate change in continental isotopic records:1-36. 
Rutllant, J.; Fuenzalida, H. 1991. Synoptic aspects of the central Chile rainfall variability associated with the Southern Oscillation. International Journal of Climatology 11 (1): 63-76.

Sáez, A.; Godfrey, L.; Herrera, C.; Chong, G.; Pueyo, J.J. 2016. Timing of west episodes in Atacama Desert over the last $15 \mathrm{ka}$ : the groundwater discharge deposits (GWD) from Domeyko Range at $25^{\circ} \mathrm{S}$. Quaternary Science Reviews 145: 82-93.

Scott, C.; Lohman, R.; Jordan, T.E. 2017. InSAR constraints on soil moisture evolution after the March 2015 extreme precipitation event in Chile. Scientific Reports 7: 4903.

Stein, A.F.; Draxler, R.R.; Rolph, G.D.; Stunder, B.J.B.; Cohen, M.D.; Ngan, F. 2015. NOAA's HYSPLIT atmospheric transport and dispersion modeling system. Bulletin of the American Meteorological Society 96 (12): 2059-2077.

Strauch, G.; Oyarzún, R.; Reinstorf, F.; Oyarzún, J.; Schirmer, M.; Knöller, K. 2009. Interaction of water components in the semi-arid Huasco and Limarí river basins, North Central Chile. Advances in Geosciences 22 (22): 51-57.

Tapia, L.; Jordan, T.; Riquelme, R.; Herrera, C.; Centella, K.; Ramos, H.; Venegas, M. 2015. Relación entre las distintas superficies y sus perfiles de humedad, post precipitaciones de marzo 2015, en la Sierra de Varas, II Región de Antofagasta, Chile. In Congreso Geológico Chileno, No. 14: 4 p. La Serena.

Uribe, J.; Muñoz, J.F.; Gironás, J.; Oyarzún, R.; Aguirre, E.; Aravena, R. 2015. Assessing groundwater recharge in an Andean closed basin using isotopic characterization and a rainfall-runoff model: Salar del Huasco basin, Chile. Hydrogeology Journal 23 (7): 1535-1551.

Vargas, G.; Ortlieb, L.; Rutllant, J. 2000. Aluviones históricos en Antofagasta y su relación con eventos El Niño/Oscilación del Sur. Revista Geológica de Chile 27 (2): 157-176. doi: 10.5027/andgeoV27n2-a02.

Vargas, G.; Rutllant, J.; Ortlieb, L. 2006. ENSO tropicalextratropical climate teleconnections and mechanisms for Holocene debris flows along the hyperarid coast of western South America (17-24 $\left.{ }^{\circ} \mathrm{S}\right)$. Earth and Planetary Science Letters 249 (3): 467-483.

Vuille, M.; Ammann, C. 1997. Regional snowfall patterns in the high, arid Andes. Climatic Change 36 (3): 413-423.

Vuille, M.; Keimig, F. 2004. Interannual variability of summertime convective cloudiness and precipitation in the central Andes derived from ISCCP-B3 data. Journal of Climate 17: 3334-3348.

Warren-Rhodes, K.A.; Rhodes, K.L.; Pointing, S.B.; Ewing, S.A.; Lacap, D.C.; Gómez-Silva, B.; Amundson, R.; Friedmann, E.I.; McKay, C.P. 2006. Hypolithic cyanobacteria, dry limit of photosynthesis, and microbial ecology in the hyperarid Atacama Desert. Microbial Ecology 52 (3): 389-398.

West, A.G.; February, E.C.; Bowen, G.J. 2014. Spatial analysis of hydrogen and oxygen stable isotopes (isoscapes) in ground water and tap water across South Africa. Journal of Geochemical Exploration 145: 213-222.

Wilcox, A.; Escauriaza, C.; Agredano, R.; Mignot, E.; Zuazo, V.; Otárola, S.; Castro, L.; Gironás, J.; Cienfuegos, R.; Mao, L. 2016. An integrated analysis of the March 2015 Atacama floods. Geophysical Research Letters 43: 8035-8043.

Manuscript received: June 26, 2017; revised/accepted: May 29, 2018; available online: September 28, 2018. 


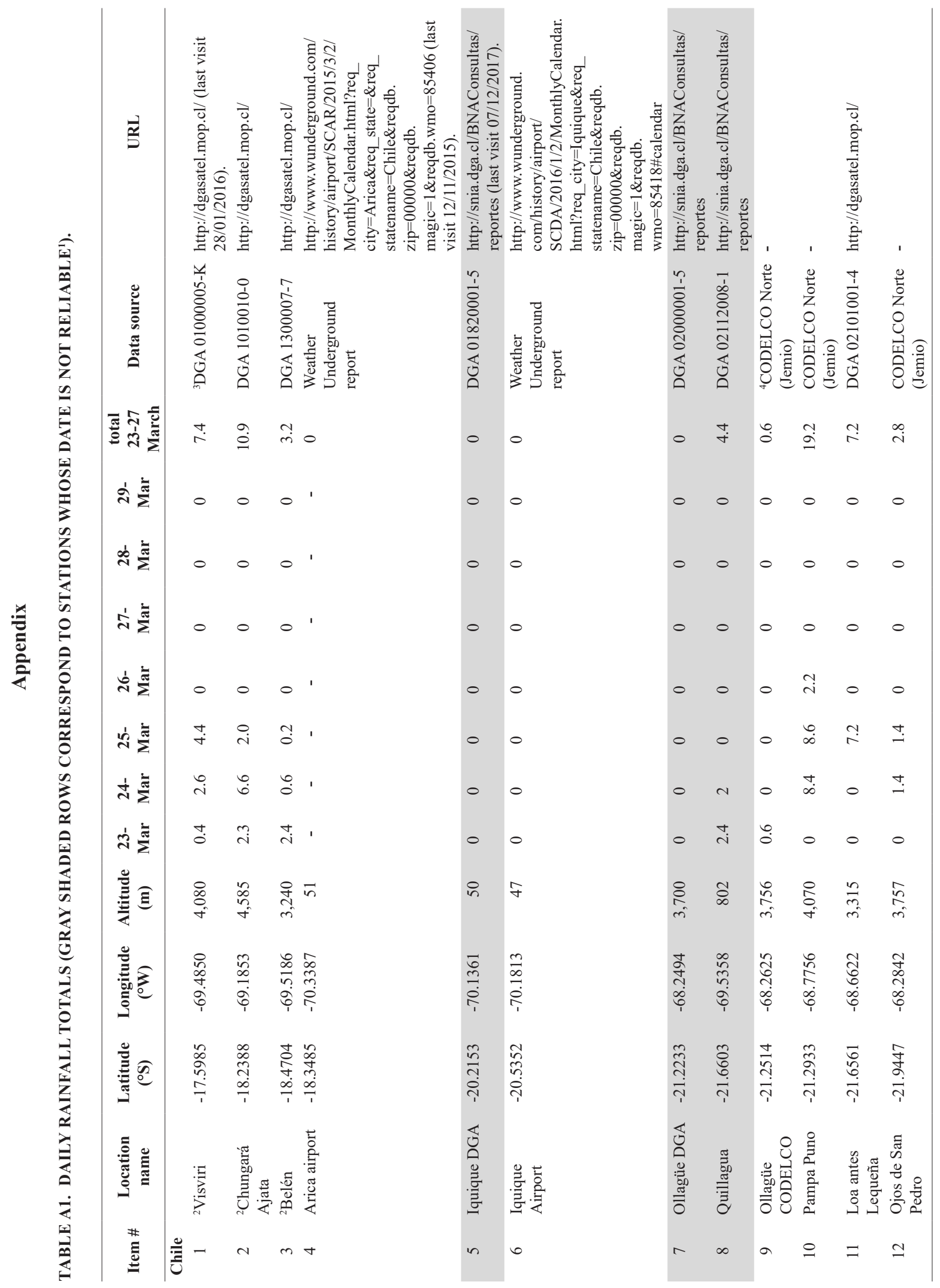




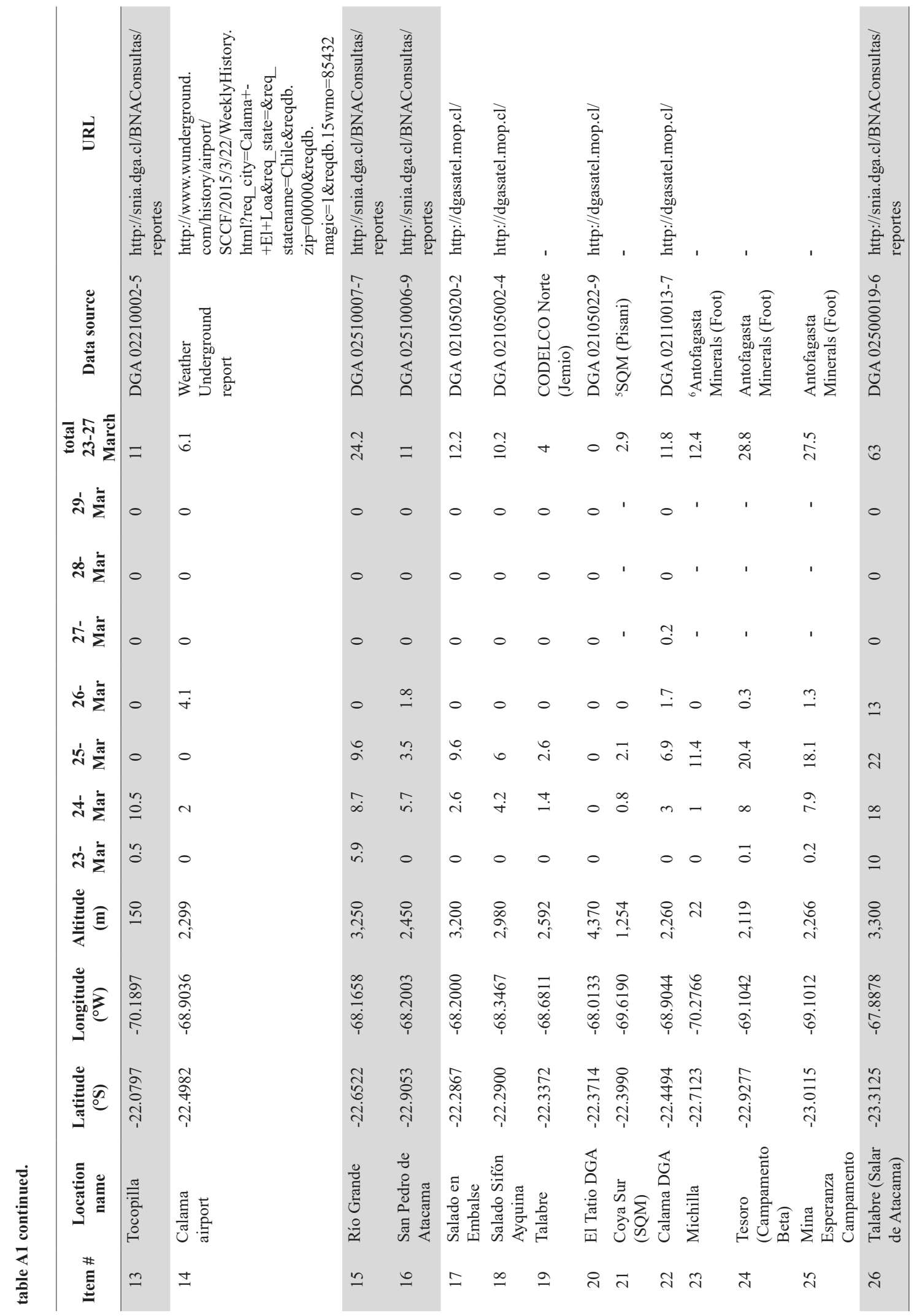




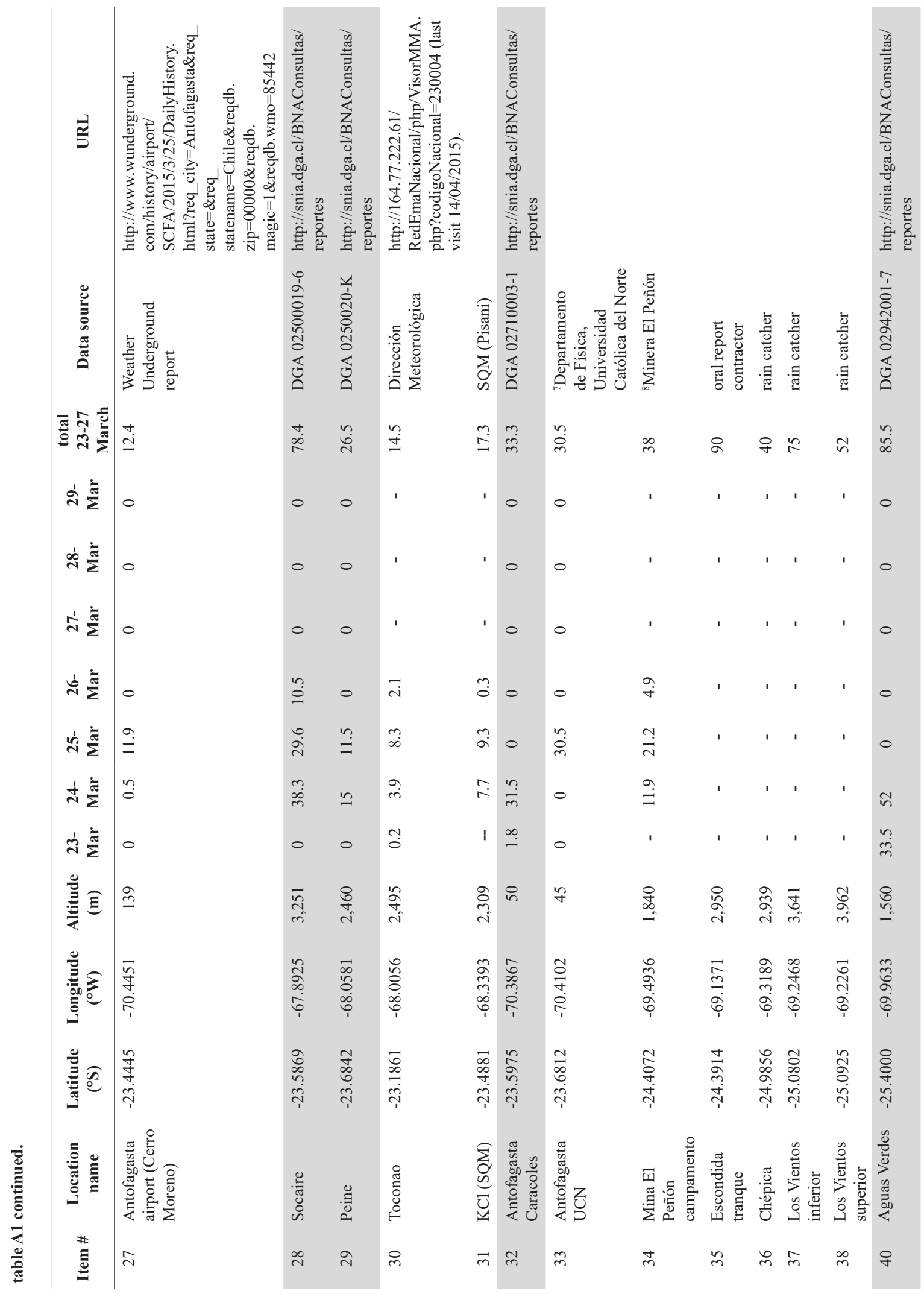



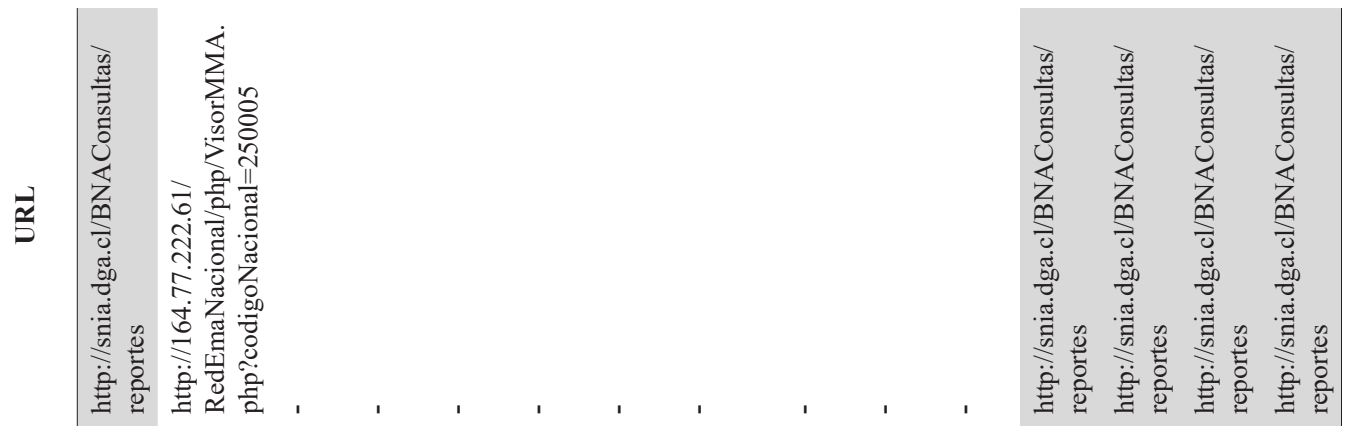

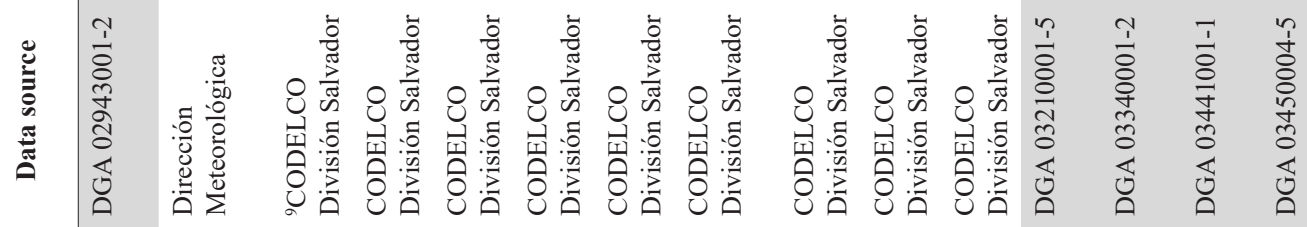

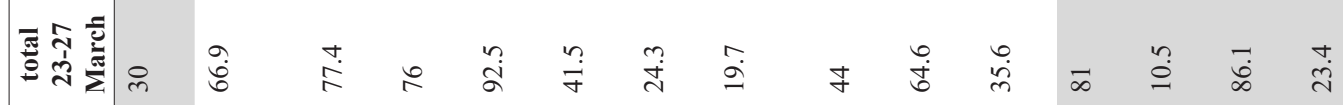
ล่ं

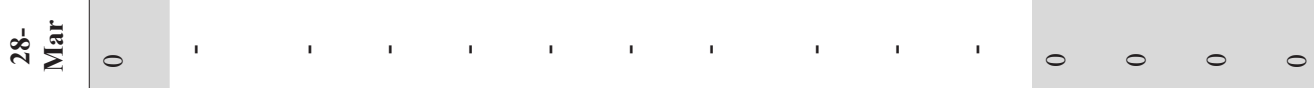
市蓄 0

ஸें⿰彳

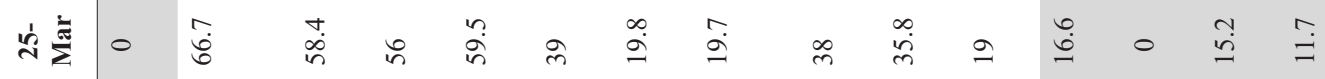

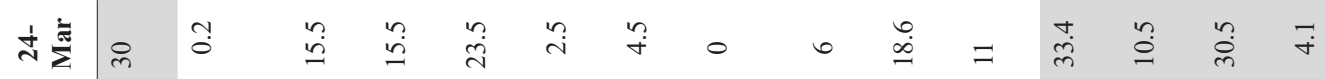
ஸे

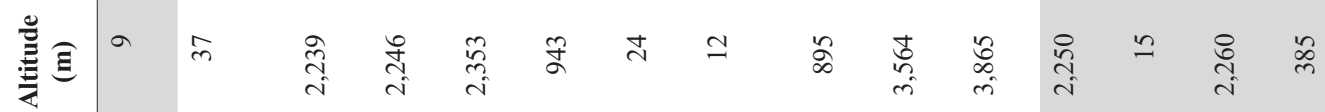

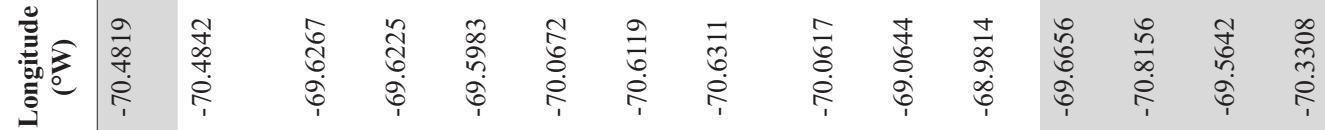

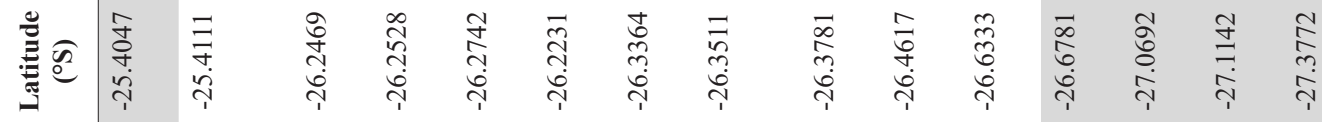

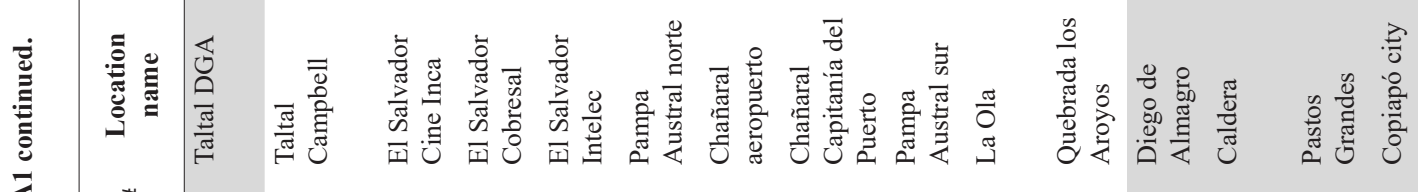
芯 


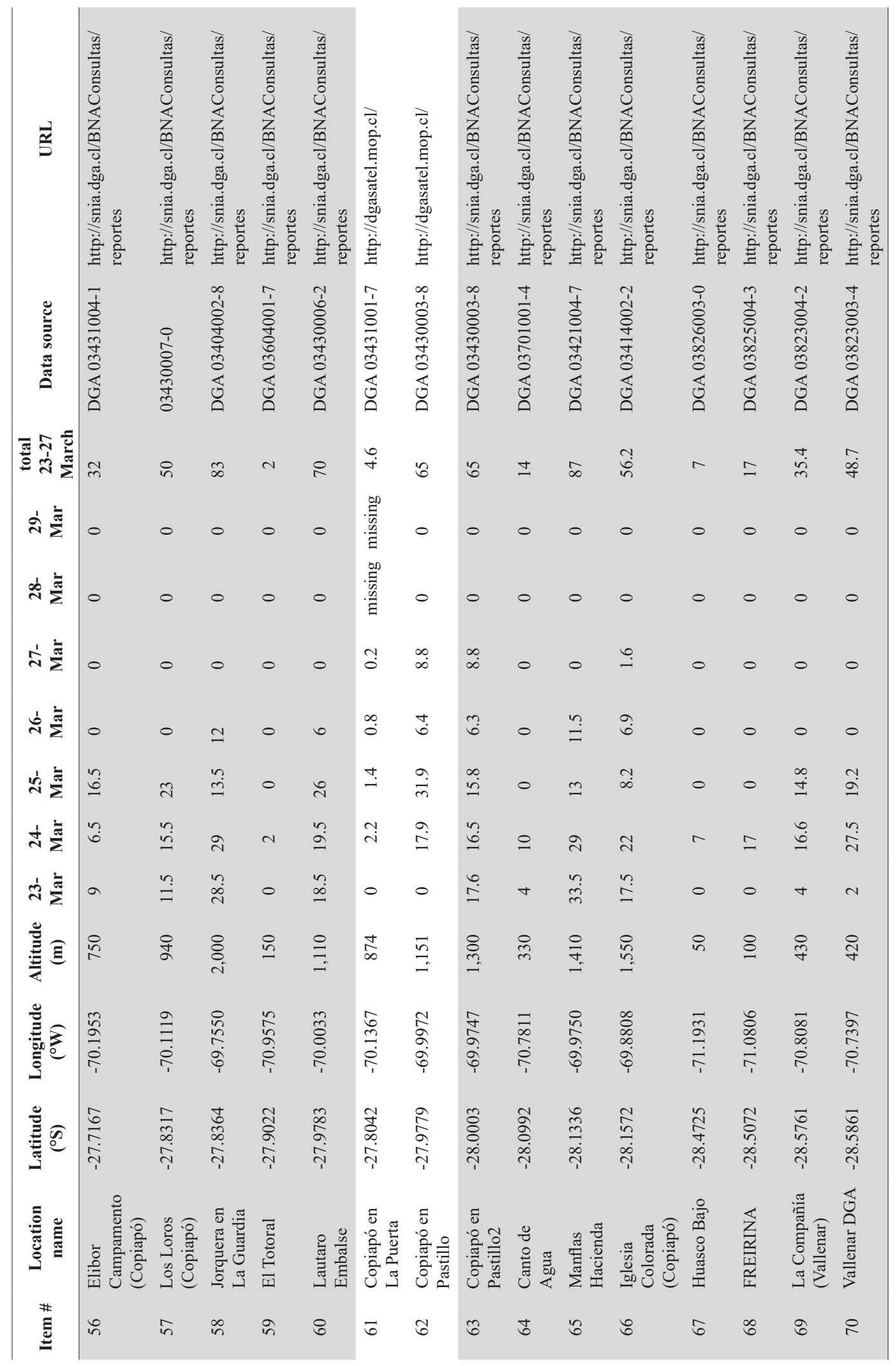




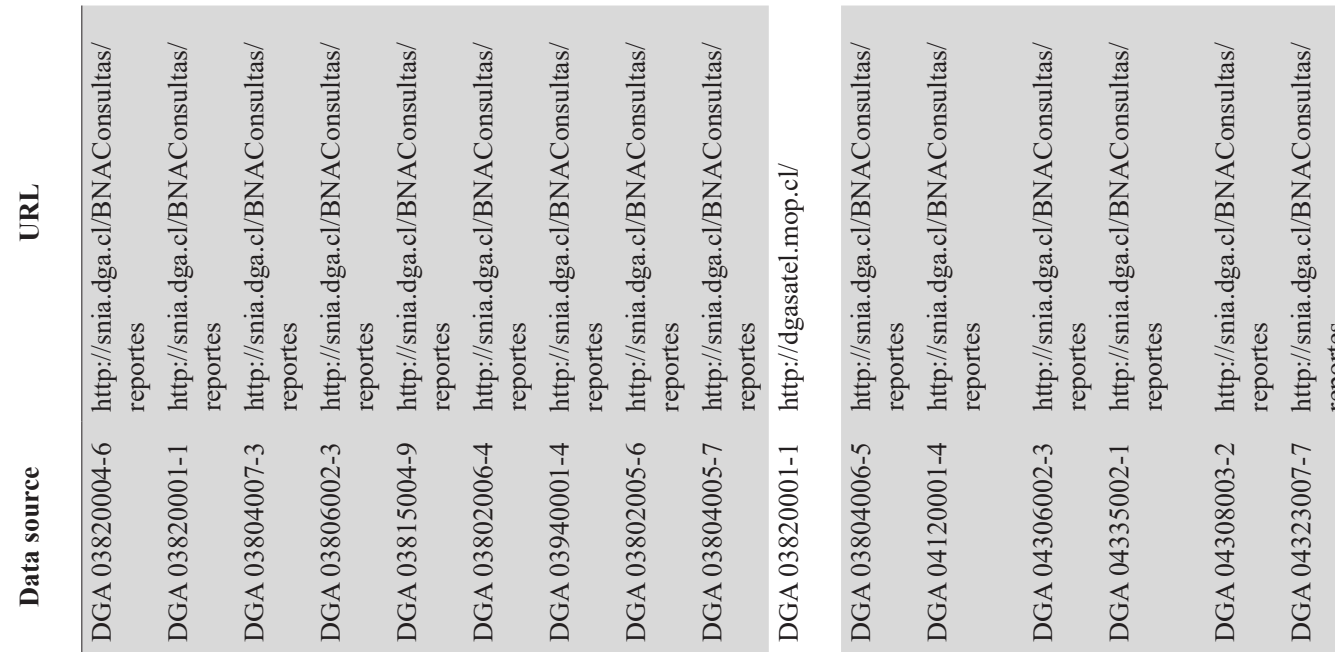

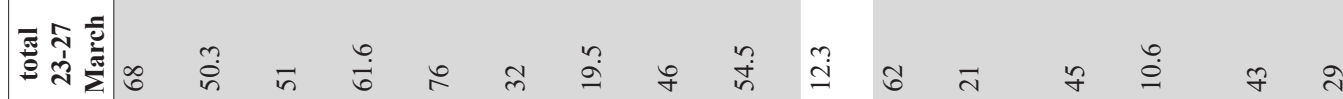

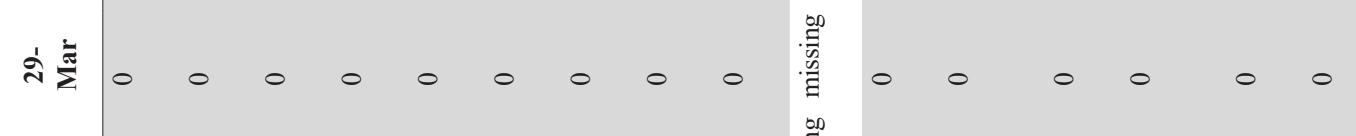

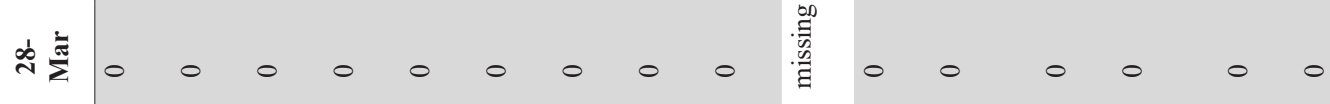

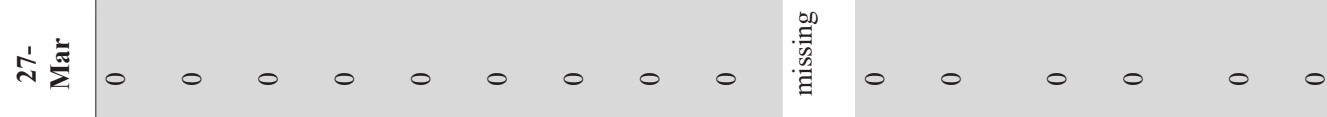

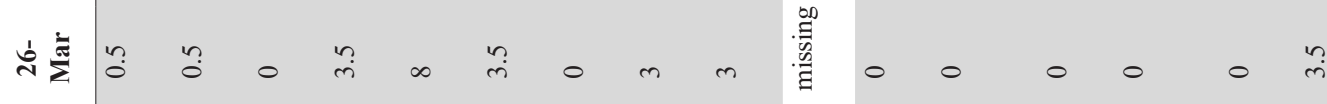

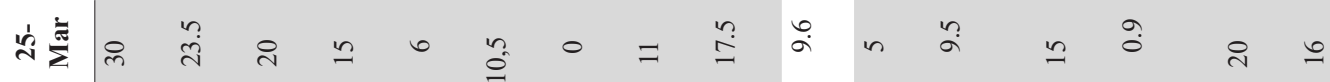

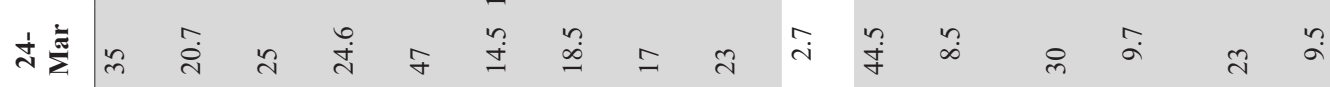

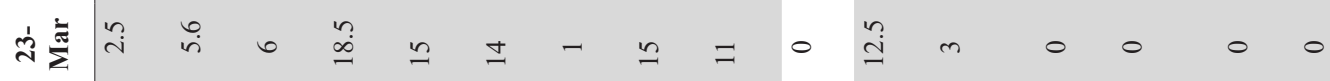
冚

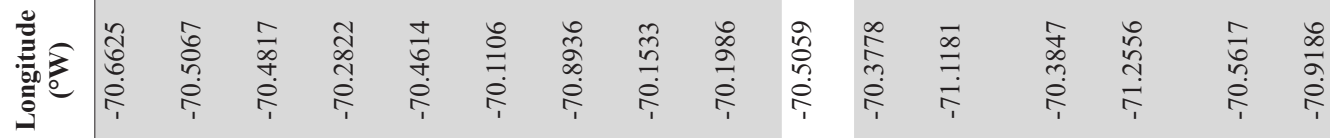

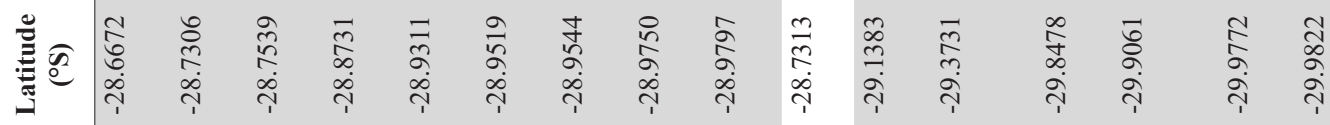

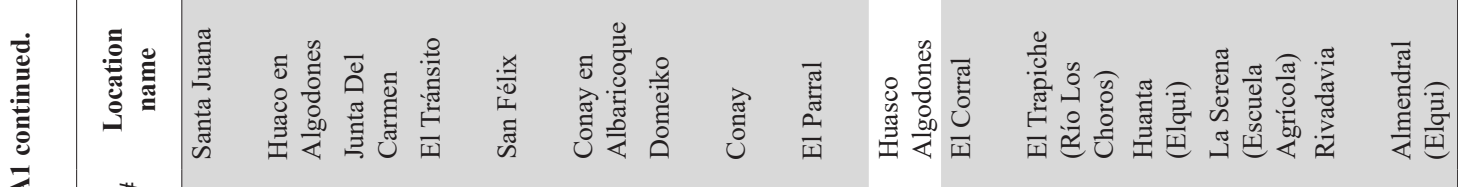
焉 


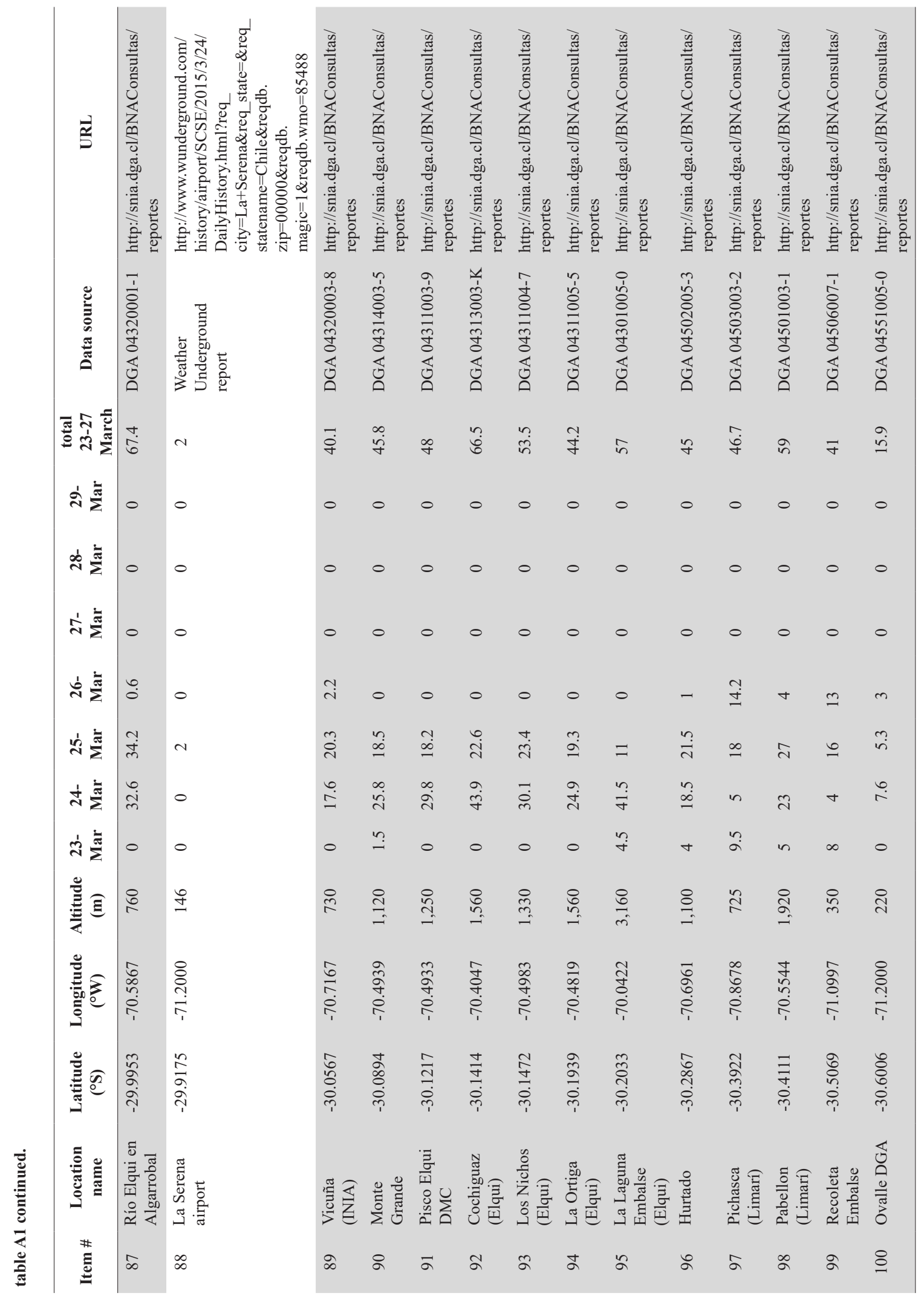




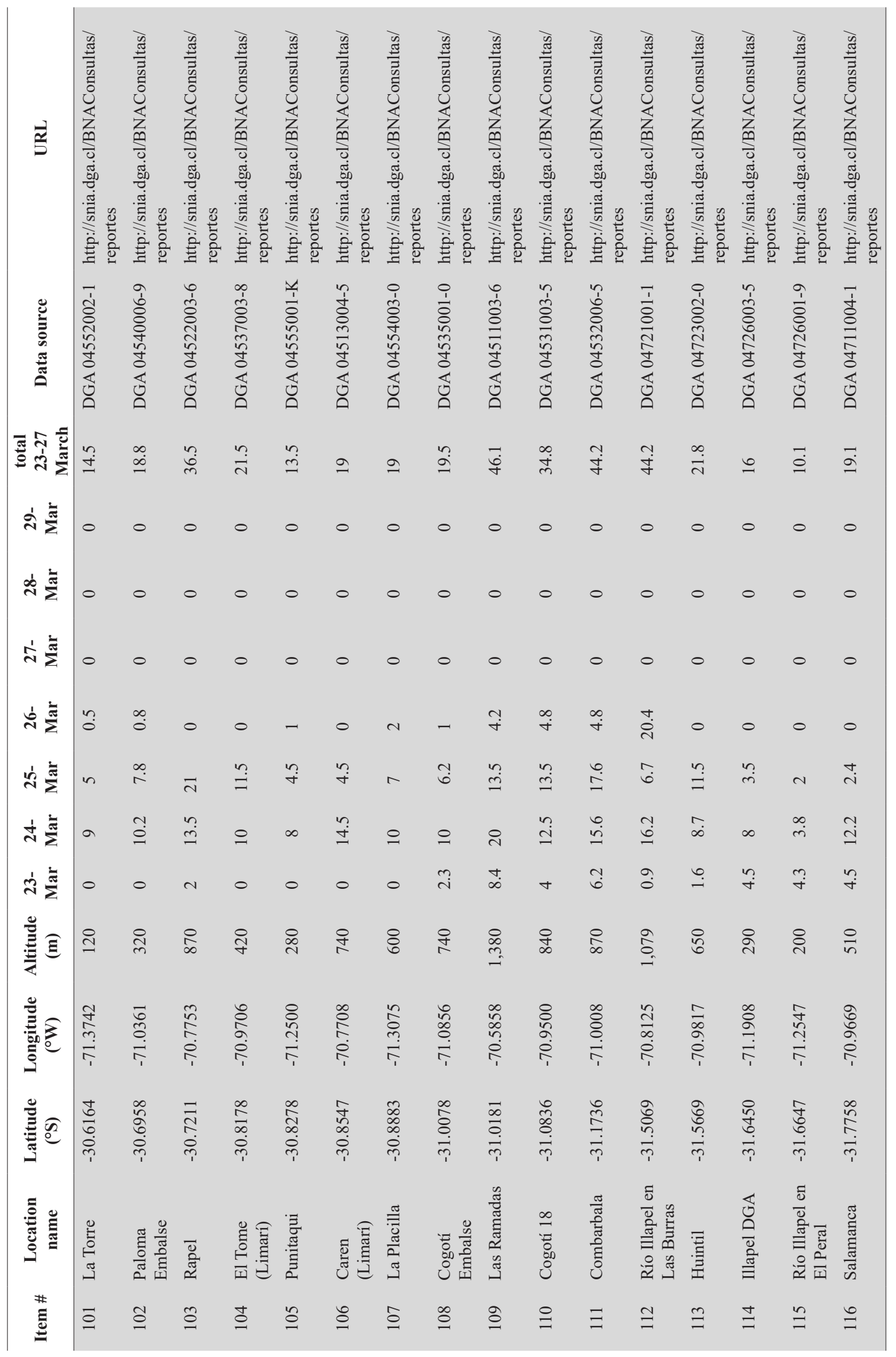




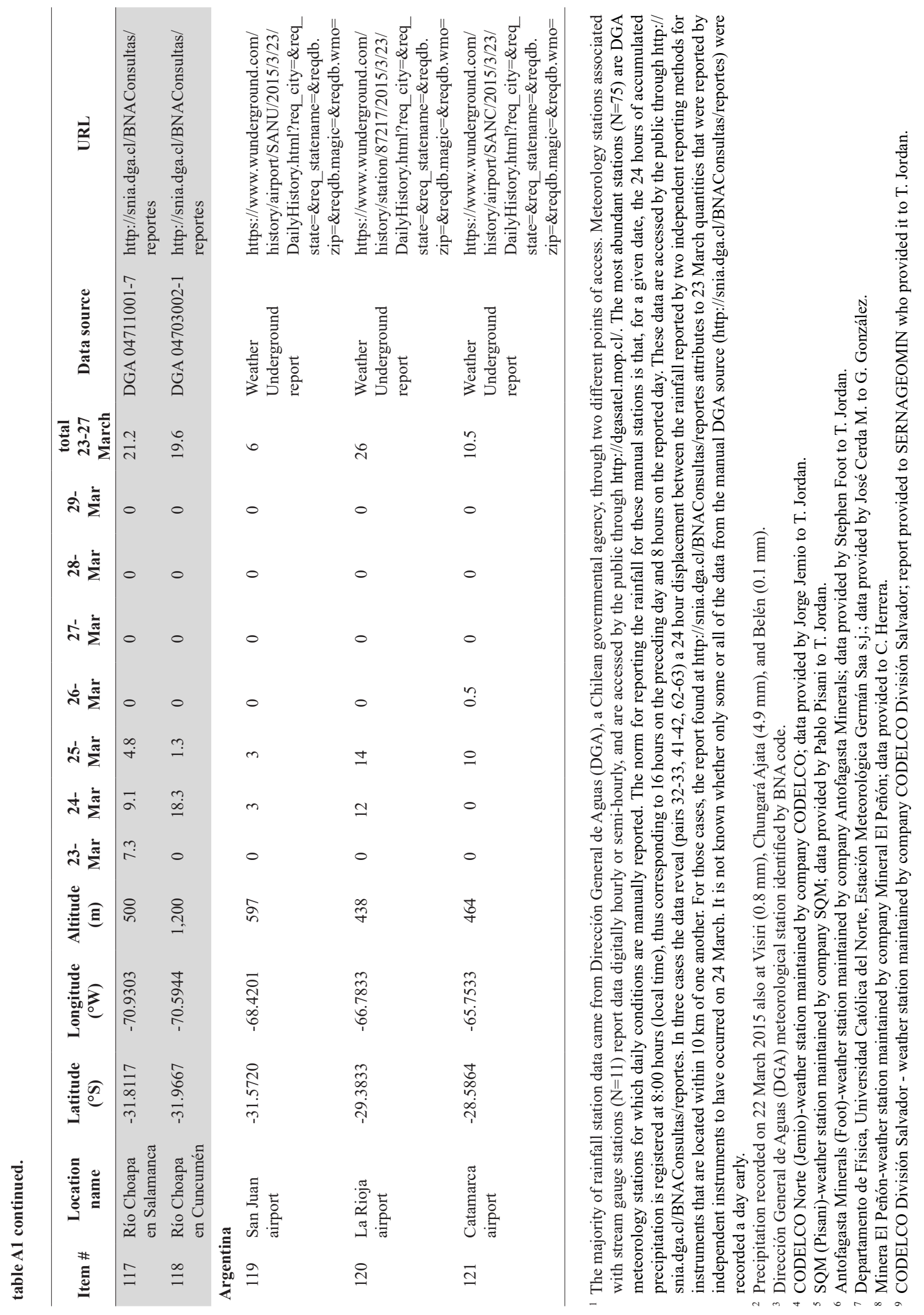


TABLE A2. SNOW STATION REPORTS IN CHILE.

\begin{tabular}{|c|c|c|c|c|c|c|c|}
\hline $\begin{array}{c}\text { Station } \\
\text { name }\end{array}$ & $\begin{array}{l}\text { Latitude } \\
\left({ }^{\circ} S\right)\end{array}$ & $\begin{array}{c}\text { Longitude } \\
\left({ }^{\circ} \mathbf{W}\right)\end{array}$ & $\begin{array}{l}\text { Altitude } \\
\text { (m) }\end{array}$ & $\begin{array}{l}\text { Data } \\
\text { source }\end{array}$ & URL* & $\begin{array}{c}\text { Time span of } \\
\text { snow }\end{array}$ & $\begin{array}{l}\text { Cumulative } \\
\text { depth (cm) }\end{array}$ \\
\hline $\begin{array}{l}\text { Quebrada } \\
\text { Larga }\end{array}$ & 30.7473 & 70.4197 & 3,500 & $\begin{array}{l}\text { DGA } \\
04520006-K\end{array}$ & $\begin{array}{l}\text { http://dgasatel. } \\
\text { mop.cl/ }\end{array}$ & $\begin{array}{l}4: 40 \text { hours } 25 \\
\text { March to } 4: 40 \\
\text { hours 26March }\end{array}$ & $15 \mathrm{~cm}$ \\
\hline $\begin{array}{l}\text { Cerro Vega } \\
\text { Negra }\end{array}$ & 31.0215 & 70.5881 & 3,600 & $\begin{array}{l}\text { DGA } \\
04511004-4\end{array}$ & $\begin{array}{l}\text { http://dgasatel. } \\
\text { mop.cl/ }\end{array}$ & $\begin{array}{l}\text { 15:52 hours } 24 \\
\text { March to 21:52 } \\
\text { hours 25 March }\end{array}$ & $55 \mathrm{~cm}$ \\
\hline
\end{tabular}

* Last visit 19/03/2016. 